\title{
Animal Models of Human Cerebellar Ataxias: a Cornerstone for the Therapies of the Twenty-First Century
}

\author{
Mario Manto • Daniele Marmolino
}

Published online: 8 August 2009

(C) Springer Science + Business Media, LLC 2009

\begin{abstract}
Cerebellar ataxias represent a group of disabling neurological disorders. Our understanding of the pathogenesis of cerebellar ataxias is continuously expanding. A considerable number of laboratory animals with neurological mutations have been reported and numerous relevant animal models mimicking the phenotype of cerebellar ataxias are becoming available. These models greatly help dissecting the numerous mechanisms of cerebellar dysfunction, a major step for the assessment of therapeutics targeting a given deleterious pathway and for the screening of old or newly synthesized chemical compounds. Nevertheless, differences between animal models and human disorders should not be overlooked and difficulties in terms of characterization should not be occulted. The identification of the mutations of many hereditary ataxias, the development of valuable animal models, and the recent identifications of the molecular mechanisms underlying cerebellar disorders represent a combination of key factors for the development of anti-ataxic innovative therapies. It is anticipated that the twenty-first century will be the century of effective therapies in the field of cerebellar ataxias. The animal models are a cornerstone to reach this goal.
\end{abstract}

Keywords Cerebellum · Ataxias · Animal models · Pathogenesis - Therapies

M. Manto $(\bowtie) \cdot$ D. Marmolino

FNRS - Laboratoire de Neurologie Expérimentale,

Université Libre de Bruxelles, ULB-Erasme,

Route de Lennik 808,

1070 Brussels, Belgium

e-mail: mmanto@ulb.ac.be

M. Manto

FNRS,

Brussels, Belgium
Advances in genetic studies, detailed molecular and cellular analyses, recent brain imaging techniques, emergence of behavioral assessments, and reshaping of models of cerebellar function are generating a massive amount of knowledge [1]. Cerebellar ataxias are being growingly recognized worldwide. There is a medical need to develop effective therapies in this group of disabling disorders for which no cure is currently available. For the first time, innovative therapeutics aiming to target deleterious pathways are under development [2]. Major breakthroughs in our understanding of the pathogenesis of cerebellar ataxias have been reached especially with the elaboration of relevant animal models reproducing human brain disorders. These models have contributed to the deciphering of the molecular mechanisms underlying cell loss.

\section{Classification of Cerebellar Ataxias}

Cerebellar ataxias represent a heterogeneous group of disorders characterized by a lack of coordination and imbalance [3, 4]. Patients exhibit various combinations of oculomotor deficits, dysarthria, dysmetria, and kinetic tremor. Various forms of learning are impaired [5]. Recently, the association of cerebellar lesions and neuropsychiatric symptoms has been underlined [6-8]. Some ataxic diseases show a marked cognitive dysfunction [9, 10].

Cerebellar disorders can be classified into inherited and sporadic ataxias. Inherited ataxias are related to a genetic deficit and can be divided into four groups: autosomal dominant ataxias, autosomal recessive ataxias, mitochondrial ataxias, and X-linked ataxias [3]. Dominant ataxias include the so-called spinocerebellar ataxias (SCAs) and the episodic ataxias (EAs) $[11,12]$. SCAs are a set of genetic and clinically heterogeneous diseases which share the 
feature of progressive lack of coordination. SCAs are classified genetically according to a specific mutation or mapped locus and also according to clinical findings [13-15]. The majority of known mutations involve a sequence of $\mathrm{CAG}$ trinucleotide repeats within the coding tract in the respective gene $[2,16,17]$. This is the case for SCA1, SCA2, SCA3, SCA6, SCA7, SCA17, and dentatorubral-pallidoluysian atrophy (DRPLA). A CTG repeat expansion is found in SCA8 $[18,19]$. Trinucleotide repeats are associated with an abnormal polyglutamine accumulation and formation of nuclear aggregates [20]. A pentanucleotide repeat expansion ATTCT is associated with SCA10 [21]. SCA5, SCA13, SCA14, and 16q22-linked autosomal dominant cerebellar ataxia are characterized by point mutations. Episodic ataxias are a group of diseases caused by a monogenic mutation (EA 1-7) and displaying attacks of incoordination and dysarthria. Autosomal recessive ataxias include Friedreich's ataxia (FRDA) due to a pathological GAA triplet expansion within the first intron of the frataxin gene, ataxia telangiectasia, ataxia with ocular motor apraxia, ataxia with vitamin E deficiency (AVED), ataxia with $\mathrm{CoQ} 10$ deficiency, abetalipoproteinemia, earlyonset cerebellar ataxia with retained tendon reflexes, infantile onset spinocerebellar ataxia, Marinesco-Sjögren syndrome, Wilson disease, and spastic ataxia of CharlevoixSaguenay $[15,22]$. There are numerous additional types of recessive ataxias worldwide, identified in a few families only. The group of mitochondrial disorders includes diseases due to mutations in mitochondrial genes. Most of these genes are involved in the energy production, essentially in oxidative phosphorylation. Ataxia may be a main symptom, especially in Kearns-Sayre syndrome; May-White syndrome; mitochondrial neurogastrointestinal encephalomyopathy (ophthalmoparesia, peripheral neuropathy, and gastrointestinal symptoms); Leigh syndrome; neuropathy, ataxia, and retinitis pigmentosa; mitochondrial encephalomyopathy, lactic acidosis with stroke-like episodes; and myoclonus epilepsy with ragged red fibers. $\mathrm{X}$-linked ataxias include Fragile-X tremor ataxia syndrome, caused by a CGG mutation on the $\mathrm{X}$ chromosome.

Sporadic ataxias can be subdivided in (1) degenerative and (2) acquired ataxias [23]. Degenerative ataxias include multiple system atrophy (MSA) and idiopathic late-onset cerebellar ataxia. MSA is a progressive adult-onset disease, with two main presentations: a cerebellar form (c-MSA) and a parkinsonian form (p-MSA) [24]. Several drugs or toxics can trigger a cerebellar syndrome. The most common cerebellotoxic agent is alcohol $[25,26]$. Immune-mediated ataxias include multiple sclerosis, cerebellar ataxia with antiglutamic acid decarboxylase antibodies, gluten ataxia, Miller-Fisher syndrome, systemic lupus erythematosus, Sjögren syndrome, Cogan syndrome, and thyroiditis $[27,28]$.

\section{Animal Models}

In this issue, we have gathered several contributions which highlight the roles of animal models in our understanding of cerebellar disorders. Tables 1, 2, 3, and 4 summarize the animal models and their corresponding human disorder.

\section{Models of Hereditary Ataxias}

The number of models of hereditary ataxias in rodents has increased noticeably [99]. The naturally occurring ataxic mutant mice which have been investigated in depth are the Lurcher mouse (gain in malfunction of the Grid2 gene encodes the GluR $\delta 2$ ionotropic glutamate receptor), the hot-foot mouse (different deletions in the coding sequences of Grid2), the staggered mouse (deletion of the Rora gene located on chromosome 9), the Purkinje cell degeneration (pcd) mouse (mutation of the Agtpbp1 gene located on chromosome 13; see below), the nervous mouse, the reeler mouse (mutation disrupting the Reln gene on chromosome 5 ), the weaver mouse (involving an inward rectifying potassium channel strongly expressed in cerebellum), and the dystonia musculorum mouse (mutation of the Dst gene located on chromosome 6) [100-102]. A substantial number of transgenic mice with induced mutations have also been generated [33].

Lee and Jeong report on the Pogo (pogo/pogo) mouse, a naturally occurring neurological mutant from a Korean wild-type mouse KJR/MsKist [103]. The pogo mouse is characterized by a loss of balance and motor coordination. Gait is wobbly. The tendency to fall over appears at about 2 weeks of age and continues throughout life. The Pogo mutation is believed to be an allele of $\mathrm{P} / \mathrm{Q}$-type calcium channel mutants such as tottering, leaner, and rolling mouse Nagoya (see below). These channels play crucial roles in neuronal signaling and in neurotransmitter release at many central synapses and at the neuromuscular junction. The pogo mutation is inherited as an autosomal recessive trait. The pogo locus has been mapped to a region between D8Mit67 and D8Mit240 on mouse chromosome 8 [104]. The tottering and its allele leaner and rolling mouse Nagoya have been mapped to the D8Mit128/D8Mit231 marker region. These mutants have been studied as models of spinocerebellar ataxia and epilepsy. The mutation responsible for tottering has been mapped to Cacnala, a gene encoding the alpha subunit of a P/Q-type calcium channel [37]. Mutations in Cacnala are responsible in tottering alleles for seizures, cerebellar degeneration, and ataxia [105]. Mutations in the human CACNA1A gene have been found in three inherited disorders belonging to the family of channelopathies: familial hemiplegic migraine, episodic ataxia type 2, and spinocerebellar ataxia type 6 [106]. The homozygous pogo/pogo phenotype is similar to that of 
Table 1 Animal models of dominant ataxias

\begin{tabular}{|c|c|c|}
\hline Type & Gene mutation & Animal model \\
\hline SCA1 & CAG (35-83) & $\begin{array}{l}\text { Mice }(C A G 82 Q), \mathrm{L} 7 \text { promoter, mice }(C A G 82 Q), \mathrm{L} 7 \text { conditional promoter; mice } \\
\text { knock-in }(C A G 154 Q)[29-33]\end{array}$ \\
\hline $\mathrm{SCA} 2$ & CAG $(34-750)$ & Mice (CAG58Q), L7 promoter [34] \\
\hline SCA3 & CAG (56-86) & Mice $(Y A C-M J D 1 / C A G 67-84 Q)$, MJD1 promoter; mice (mjdala-CAG71Q) $[35,36]$ \\
\hline SCA4 & - & Mice (tottering, $t g$ and $t g-l a)$ mutants, mice $\left(\right.$ Cacnala $\left.{ }^{R 192 Q}\right)$, mice (Cacnala-CAG84Q) [37-39] \\
\hline SCA5 & Missense mutations & - \\
\hline SCA6 & CAG (19-33) & Mice (Cacnala-CAG84Q) [40] \\
\hline SCA7 & CAG (41-306) & $\begin{array}{l}\text { Mice }(C A G 90 Q) \text {, promoter L7, mice }(C A G 128) \text { promoter PDGF-B, mice }(C A G 92) \text {, } \\
\text { promoter Prp, mice }(C A G 266 Q)[40-42]\end{array}$ \\
\hline SCA8 & CTG $(80-300)$ & Mice (CTG116) $[43,44]$ \\
\hline SCA10 & ATTCT $(800-4500)$ & $\operatorname{Mice}\left(\operatorname{Atxn} 10^{-/-}\right)[21]$ \\
\hline SCA11 & - & - \\
\hline SCA12 & CAG (66-93) & - \\
\hline SCA13 & - & - \\
\hline SCA14 & Missense mutations & Mice (curly tail) mutant [45] \\
\hline SCA15 & - & Mice $\left(\right.$ ItprlEXdel $\left.{ }^{18}\right)[46]$ \\
\hline SCA16 & - & - \\
\hline SCA17 & CAG/CAA (43-63) & Xenopus (antisense-targeting tbp), mice (Tbp delta- $N)$, mice $\left(\mathrm{tbp}^{-/-}\right)$[47-50] \\
\hline SCA18 & - & - \\
\hline SCA19 & - & - \\
\hline SCA20 & - & - \\
\hline SCA21 & - & - \\
\hline SCA22 & - & - \\
\hline SCA25 & - & - \\
\hline DRPLA & CAG (48-93) & Mice (DRPLA-CAG76Q), mice (full-length humanDRPLA) $[51,52]$ \\
\hline FGF14 & FGF 14 & - \\
\hline
\end{tabular}

tottering alleles. However, pogo mouse frequent falls backward as a result of hindlimb overextension [107]. The pathological defects are mainly located to the cerebellum [103]. In P/Q-type voltage calcium channel (Cav2.1) mutant mice, Purkinje cell loss is not associated with the onset or development of ataxia but rather reflects the degree of the ataxic phenotype [105]. Tyrosine hydroxylase (TH), the ratelimiting enzyme in the biosynthetic pathway of the catecholamines, is expressed transiently during development and is low or absent in the adult mouse [108]. TH is ectopically expressed in Purkinje cells of several ataxic mutant mice including tottering alleles $\left(\mathrm{tg} / \mathrm{tg}, \mathrm{tg}^{\mathrm{la}} / \mathrm{tg}^{\mathrm{la}}, \mathrm{tg}^{\mathrm{rol}} / \mathrm{tg}^{\mathrm{rol}}\right)$ and dilute-lethal $\left(\mathrm{d}^{1} / \mathrm{d}^{1}\right)$ mutant mice $[109,110]$. Interestingly, ectopic TH expression is conspicuous in a subpopulation of Purkinje cells in the Pogo mouse, and TH immunoreactive Purkinje cells are clustered in an array of parasagittal stripes. Almost all TH immunoreactive Purkinje cells express zebrin II [111].

Plomp et al. discuss the neuromorphological and electrophysiological findings in the rolling Nagoya mouse [112]. This mouse was initially reported by Oda [113]. The mutation was identified in 2000 [114]. The phenotype in homozygous mice is characterized by a broad-based, severe ataxic gait. Mice exhibit frequent lurching and abnormal cyclic movements of the hind limbs when walking, rolling on their back or side. Symptoms become obvious between postnatal days 10 and 14. Overall, the ataxia is more severe than in tottering but less severe than in leaner mice. Rolling Nagoya mice do not show absence seizures, motor seizures, or paroxysmal dyskinesias, which might be an advantage for testing the anti-ataxic effects of drugs, in the context of human CACNA1A mutation-related cerebellar ataxia [115, 116]. The mutation causes a charge-neutralizing amino acid change from a highly conserved arginine to glycine at position 1262 in the Cav2.1- $\alpha 1$ protein [114]. This mutation impairs the characteristic pattern of positively charged amino acids of one of the channel's voltage sensors, reducing the voltage sensitivity of the channel. Firing patterns in Purkinje neurons are aberrant. The R1262G mutation leads to reduced $\mathrm{Ca}++$ influx in cerebellar and other neurons that express the channel, leading to aberrant expression of many neuronal proteins and possibly also to the apoptosis of some neurons.

Bitoun and Davies review the characterization of a novel model of autosomal dominant cerebellar ataxia in mouse 
Table 2 Models of recessive ataxias

\begin{tabular}{|c|c|c|}
\hline Type of ataxia & Locus & Model \\
\hline FRDA & $9 \mathrm{q} 13$ & $\begin{array}{l}\text { Mice }(M C K), \text { promoter muscle creatine kinase, } \\
\text { mouse }(N S E) \text {, promoter neuronal enolase, } \\
\text { mice }\left(C r e-E R^{T}\right), \text { promoter Prp, mice }\left(K I K O^{G A A 230 /-}\right) \\
\left.\text { mice }\left(K I K I^{G A A 230 / 230}\right) \text {, mice (human } G A A / F X N-Y A C\right) \text {, } \\
\text { C. elegans mutants (frh-1), Drosophila mutants }(d f h) \\
\text { [53-59] }\end{array}$ \\
\hline Familial coenzyme Q10(CoQ10) deficiency & CoQ10 & $\begin{array}{l}\text { Mice }\left(\text { clk }^{-/-}\right) \text {, mice }\left(\operatorname{coq} T^{--}\right), \text {C. elegans }\left(c l k-1^{-/}\right) \text {, } \\
\text { Saccharomyces cerevisiae }(\text { coq1-coq } 8) \text { mutants, diet } \\
\text { depletion models }[60-63]\end{array}$ \\
\hline Autosomal-recessive spastic ataxia of Charlevoix-Saguenay & $13 \mathrm{q} 12$ & Mice (tumbler) mutant [64] \\
\hline Early onset cerebellar ataxia with retained tendon reflexes & $13 q 11-12$ & - \\
\hline Mitochondrial recessive ataxic syndrome & & Mice $(P o l g A, D 257 A)[65]$ \\
\hline Marinesco-Sjögren syndrome & $5 q 32$ & Mice (woozy) mutants; mice (tumbler) mutant, [66-68] \\
\hline Joubert syndrome & $9 q 34$ & \\
\hline JBTS1 & & - \\
\hline JBTS2 & $11 \mathrm{p} 12-\mathrm{p} 13.3$ & \\
\hline JBTS3 & JBTS3 6q23 & \\
\hline JBTS4 & JBTS4 2q13 & \\
\hline \multicolumn{3}{|l|}{ JBTS5 } \\
\hline Cayman ataxia & $12 \mathrm{q} 21.32$ & Jittery mice $\left(\right.$ AtcayB $\left.11^{\text {insEX4 }}\right),[68,69]$ \\
\hline Ataxia with isolated vitamin E deficiency & $8 \mathrm{q} 13$ & Mice $\left(\alpha-T T P^{-/-}\right)$, diet restriction rat, $[70,71]$ \\
\hline Abetalipoptoteinemia (Bassen-Komzeweig syndrome) & $4 q 22-q 24$ & $\begin{array}{l}\text { Suncus murinus (suncus); mouse (apobEX26stop }{ }^{N 1785} \text { ), } \\
\text { (Apob83) mutant }[72,73]\end{array}$ \\
\hline $\begin{array}{l}\text { Hereditary motor and sensory neurophaty type IV, } \\
\text { Refsum disease }\end{array}$ & 10pter-p11.2 & Mice $\left(P h y h^{-/-}\right)[74]$ \\
\hline Cerebrotendinous xanthomatosis & 2q33-qter & $\operatorname{Mice}\left(\right.$ Cyp $\left.27^{-1}\right)[75]$ \\
\hline Metachromatic leucodystrophy & $22 \mathrm{q} 13$ & Mice $\left(A S A^{-/-}\right),\left(A S A^{-/-\mathrm{CGT}}\right)\left(A S A^{-/-\mathrm{CST}}\right)[76-78]$ \\
\hline Niemann-Pick type C & $18 \mathrm{q} 11-121$ & $\begin{array}{l}\text { Mice }\left(B A L B / c n p c^{n i h}\right), \text { Caenorhabditis elegans } \\
\quad(n p c-1, n p c-2) \text { mutants }[79,80]\end{array}$ \\
\hline $\begin{array}{l}\text { GM1 gangliosidosis GM2-gangliosidosis } \\
\text { (Tay-Sachs disease) }\end{array}$ & $3 \mathrm{p} 21.3315 \mathrm{q} 23-24$ & $\begin{array}{l}\text { Cats, cattle ,dogs ,sheep (GM1) mutants, cats (GM2) } \\
\text { mutants, mice }\left(\text { Hexa }^{-} /-\right) \text {, mice }\left(\text { Hexb }^{-} /\right) \text {, porcine } \\
\text { (GM2) mutants }[81,82]\end{array}$ \\
\hline Chorea acanthocytosis & $9 \mathrm{q} 21$ & $\operatorname{Mice}\left(C H A C d e l^{E X}\right)[60,61]$ \\
\hline Wilson's disease & $13 q 14-21$ & $\begin{array}{l}\text { Mice }\left(a t p 7 b^{-/-}\right) \text {, mouse toxic milk }(t x), \text { LEC rats, } \\
\text { bedlington terriers mutants, West Highland White } \\
\text { Terrier mutants dogs [83] }\end{array}$ \\
\hline Aceruloplasminaemia & $3 q 23-q 24$ & Mice $\left(\mathrm{Cp}^{-1-}\right)$ \\
\hline Ataxia telangiectasia & $11 \mathrm{q} 22.3$ & Mice $\left(\mathrm{atm}^{-/-}\right)$, Mice $($Atm y/y) $[85,86]$ \\
\hline Ataxia telangiectasia-like disorder & $11 \mathrm{q} 21$ & - \\
\hline Spinocerebellar ataxia with axonal neuropathy 1 & $14 \mathrm{q} 31$ & - \\
\hline Ataxia with oculomotor apraxia & $9 \mathrm{p} 13$ & - \\
\hline Ataxia with oculomotor apraxia 2 & $9 q 34$ & - \\
\hline
\end{tabular}

with growth retardation from 2 to 3 weeks of age and adultonset region-specific Purkinje cell loss, as well as cataracts and defects in early $\mathrm{T}$ cell maturation [117]. Robotic animals display an unusual jerky gait, first apparent from 3 to 4 weeks [118]. The mice show a progressive decrease in size of the molecular layer, resulting in significant atrophy of the cerebellum from 6 months [119]. The mutation involves AF4, a member of the AF4/LAF4/
FMR2 (ALF) family of transcription cofactors. In the cerebellum, the expression of AF4 gene is restricted to the Purkinje cell layer, with markedly reduced levels in lobe X. The onset of degeneration coincides with the completion of dendritic development and acquisition of mature Purkinje neuron electrophysiological properties [120]. AF4 is involved in lymphopoiesis and leukemogenesis. The Af4 knockout mouse shows severe impairment in B and $\mathrm{T}$ cell 
Table 3 Models of X-linked ataxias

\begin{tabular}{|c|c|}
\hline Disorder & Animal model \\
\hline $\begin{array}{l}\text { Fragile } X \text { tremor } \\
\text { ataxia syndrome }\end{array}$ & $\begin{array}{l}\text { Mice }\left(f m r 1^{-/-}\right), \text {Drosophila } \\
\quad(\text { Dfxr }) \text { mutants, mice } \\
\text { (fmr1-CGG102/110), Drosophila } \\
\text { (humanFMR1-CGG90) } \\
\text { [87-90] }\end{array}$ \\
\hline Arts syndrome & - \\
\hline X-linked adrenoleukodystrophy & $\begin{array}{l}\text { Mice }\left(\text { Abcd } 2^{-/}\right), \text {Drosophila } \\
\quad(\text { bubblegum })[91,92]\end{array}$ \\
\hline Congenital ataxias & - \\
\hline Rett syndrome & $\begin{array}{l}\text { Mice }\left(\text { meсp } 2^{-/-}\right), \text {mice } \\
\quad\left(\text { mecp } 2 E X^{3 / 4 m u t}\right)[93,94]\end{array}$ \\
\hline Ataxia-dementia (SCAX4) & - \\
\hline
\end{tabular}

development, especially in early stages during proliferation and recruitment of cell precursors [121]. The ALF proteins are transcriptional regulators $[122,123]$. The ALF family member FMR2 has been linked to a neurological disorder in human. Loss of FMR2 gene expression via expansion of CCG trinucleotide repeats in the $5^{\prime}$-untranslated region has been shown to cause FRAXE, an X-linked form of mild mental retardation associated with learning deficits [124]. The phenotype of the Fmr2 KO mouse is reminiscent of the human phenotype with impaired learning and memory performance [125].

Chen and colleagues underline the consequences of the mutations of the SCN8A gene, one of the sodium channel $\alpha$-subunit genes [126]. The SCN8A gene is primarily expressed in neurons and glia. In the cerebellum, the SCN8A gene is expressed in many types of neurons, including Purkinje cells, granule cells, and neurons in cerebellar nuclei [127]. A patient with cerebellar atrophy, ataxia, and mental retardation with a protein truncation mutation of sodium channel Scn8a has been reported [128].
Several mutant alleles of Scn8a have been characterized, showing various combinations of ataxia, dystonia, and muscle weakness [129-131]. Various deficits in Purkinje cell function have been found in Scn8a mutant mice, although no major loss of Purkinje cells, as reported in many other types of mutant mice, has been described except in older Scn8amedJo mice. There is a decreased density of gamma-aminobutyric acid (GABA) immunolabeling in somata of Purkinje cells in mutant mice as compared to control mice, suggesting that the decreased Purkinje cell activity in the mutant mice might be due to a downregulation of GABA metabolism [132]. Glutamine and taurine concentrations are higher in almost all brain regions of $\mathrm{Scn} 8 \mathrm{a}^{\text {medJ }}$ mice as compared to controls. Glutamine is involved in glutamate synthesis and taurine participates in osmoregulation [133]. Changes in glutamine and taurine suggest an upregulation of glial amino acid metabolism.

The clinical and genetic characterization of dominant SCAs has made a jump. About 30 SCAs are now described in details. Corresponding animal models of polyglutaminerelated neurodegeneration have been generated. Vig et al. [134] show that vacuoles appearing early in SCA1 Purkinje cells could develop through an autophagic mechanism. The degeneration of the interface between Bergmann glia and Purkinje cells results in the formation of these vacuoles. These latter cells appear earlier as compared to intranuclear inclusions and onset of behavioral abnormalities [135]. Besides transgenic mouse models, Drosophila models overexpressing the mutant protein have been generated, having analogies with the human disorder such as nuclear inclusion formation and late-onset cell degeneration [136, 137]. The gain of toxic function resulting from the protein mutation can be investigated in details. It is also of interest to compare the data obtained from cultured cerebellar cells and from in vivo studies. For instance, the mutant protein associated with SCA7 (ataxin7) activates the apoptotic
Table 4 Models of acquired ataxias

\begin{tabular}{ll}
\hline Disorder & Animal model \\
\hline Stroke & Vascular occlusion \\
& Ischemia-reperfusion model \\
Intoxication & See text \\
Tremor & Administration of harmaline [95] \\
Immune-mediated & EAE [96] \\
Infectious/para-infectious & Direct infection \\
Traumatic & Cerebellar trauma [97] \\
Paraneoplastic & Administration of antibodies \\
& Modification of the immune reaction \\
Endocrine & Reviewed in [98] \\
Developmental & Mutant studies in mouse-investigations of the foliation patterns \\
\hline
\end{tabular}


pathway, whereas in vivo models of SCA7 show ataxia and Purkinje dendrite degeneration in absence of Purkinje cell apoptosis [42, 138, 139]. Transgenic mice expressing polyQ-expanded TBP (TATA-box binding protein) have allowed the unraveling of the effects of the polyQ domain of TBP in transcriptional regulation, improving our understanding of SCA17 whose presentation is highly heterogeneous [48, 140]. Although high expression of mutant proteins in mice results in the successful generation of polyglutamine-related changes in the brain, there are still some discrepancies in terms of lesion distribution or cell types that are affected [141]. In addition, no model has yet successfully reproduced the specific neuronal loss observed in humans. The impact of neuroimaging on the appraisal of the neurodegenerative process occurring in the human cerebellum is noticeable and advanced imaging techniques are now being applied in animals with great hope [142, 143]. Quantitative methods allow an accurate estimation of components of the cerebellum, from childhood to the elderly [144]. Applications for ataxic disorders are straightforward.

A few mutant hamsters have been reported [145]. They are used as models for movement disorders such as dystonia or parkinsonism [146, 147]. Akita and Arai report on a spontaneous model of Purkinje cell loss in hamster [148]. The major clinical sign of the mutant hamsters is a moderate ataxia of gait, with trembling of the head, unsteady walking, or stumbling. This ataxia is associated with a rapid loss of the cerebellar Purkinje cell population after the third postnatal week [148]. The expression of Nna1, the gene of the pcd mutation in mice [149, 150], is almost completely suppressed in the brain of mutant hamsters. The ped mouse has been considered as an important model for understanding of cerebellar degeneration and for the evaluation of new therapies such as grafting or administration of insulin-like growth factor 1 (IGF-1) [151-153]. This latter strategy is supported by the observation that IGF-1 mRNA expression drops in cerebellar Purkinje cells of ped mouse as neurons undergo apoptosis [154]. At least ten independent phenotypic alleles of pcd have been identified so far, most studies having been performed with the $\mathrm{pcd}^{1 \mathrm{~J}}, \mathrm{pcd}^{3 \mathrm{~J}}$, and $\mathrm{pcd}^{5 \mathrm{~J}}$ mice. The $\mathrm{pcd}^{1 \mathrm{~J}}$ mice show an almost complete loss of cerebellar Purkinje cells and an indirect degeneration of granule cells [155]. Loss of Purkinje neurons occurs abruptly after the second postnatal week. Selected populations of thalamic neurons begin to degenerate at 7 weeks of age [156]. Transneuronal degeneration occurs in the inferior olivary complex and the deep cerebellar nuclei in old mutants [157]. Nnal encodes a putative zinc carboxypeptidase containing nuclear localization signals and an ATP/GTP binding motif. Nnal has been mapped to mouse chromosome 13 [151]. In adult wild-type mice, a 4-kb Nnal transcript is expressed mainly in the brain, testis, and heart [158]. Nnal expression levels in the brain of homozygous mutants are undetectable in $\operatorname{pcd}^{1 \mathrm{~J}}$ and $\operatorname{pcd}^{2 \mathrm{~J}}$ or significantly lower in $\mathrm{pcd}^{3 \mathrm{~J}}$ as compared to the wild-type control. The Nnal transgene introduced into the $\operatorname{pcd}^{3 \mathrm{~J}}$ mice under regulation of the Purkinje cell-specific L7/ pcp2 promoter rescues the neuronal cell loss as well as the ataxia, confirming that the loss of function of Nnal is responsible for the pcd phenotype [138]. Both the ataxic hamsters and the pcd mice exhibit an autosomal recessive trait, and mutant hamsters have a normal life span under conventional breeding conditions similar to the pcd mutant mice. Differences between the ataxic hamster and the pcd mouse include the moderate reduction of granule cell density in the ataxic hamster, as well as the subtle involvement of the cerebellar nuclei, inferior olivary complex, and thalamic neurons, highlighting a distinct profile of late-onset degeneration in these two animal models. Therefore, the ataxic hamster could be used to investigate cerebellar disorders characterized by relatively low levels of secondary degeneration.

Murine models of FRDA have provided insights into the early effects of frataxin deficiency. Homozygous frataxin deletion is lethal at embryonic day 6.5 [53]. Heterozygous mutant mice are totally asymptomatic (50\% residual frataxin). FRDA conditional animal models are viable [54]. The first expresses a recombinase under the muscle creatine kinase (MCK), the second under a neuron-specific enolase (NSE) promoter. In summary, these models show heart and striated muscle- or neuron-restricted deletion of frataxin [54]. Both models reproduce cardiac hypertrophy, large sensory neuron dysfunction without alteration of small sensory and motor neurons, and deficits in complexes I, III of the respiratory chain as well as aconitase activities as observed in FRDA patients. There is no skeletal muscle involvement. No increased oxidative stress is detectable in the conditional mouse models [55]. The NSE model develops progressive movement disorders characterized by gait abnormalities and loss of proprioception [54]. Electrophysiological studies reveal a specific large sensory nerve conduction defect with normal motor nerve conduction. These features mimic the abnormalities observed in patients. Another attractive murine model exhibiting the neurological features of FRDA in humans is the tamoxifeninducible recombinase $\left(\mathrm{Cre}-\mathrm{ER}^{\mathrm{T}}\right)$ under control of the mouse prion protein (Prp) promoter. The course is slowly progressive, with cerebellar and sensory ataxia in absence of motor involvement [56]. Histological lesions include posterior columns degeneration and severe lesions of Clarke's columns neurons. To study the influence of the $G A A$ repeat, the FRDA knock-in-knockout (KIKO) mouse has been generated, expressing $35-40 \%$ of wild-type residual frataxin. However, these mice do not develop phenotypic abnormalities similar to FRDA patients. Mice 
homozygous for the knock-in allele containing the $(G A A)$ 230 repeat (KIKI) have become a valuable tool for evaluating epigenetic changes associated with GAA expansion and correlating them with frataxin expression. Several Caenorhabditis elegans models with knockdown have been created to study the role of the frataxin homolog frh-1. These animals have extended life span despite a small body size, reduced fertility, and altered response to oxidative stress [57]. The frataxin knockdown animals present a consistent pleiotropic phenotype (slow growth, egg-laying defects, abnormal pharyngeal pumping, and defecation defects) associated with an increased sensitivity to oxidative stress [58]. The UAS-GAL4 transgene-based RNAi method has also been used to impose downregulation of the Drosophila frataxin homolog (dfh). This model mimics FRDA phenotype. The function of $d f h$ is essential during development [59]. Flies exhibit a markedly reduced life span and a slight decline in climbing ability [159].

The neurological symptoms and pathological findings observed in $\alpha$-tocopherol knockout mice $\left(\alpha-\right.$ TTP $\left.^{-/}\right)$closely resemble those of AVED in human [72]. Mice are normal until the age of 1 year. Deficient mice on normal or deficient $\alpha$-tocopherol diet show shaking of the head and mild ataxia while walking. Abnormalities worsened gradually and, at the age of 18 months, mice develop tremor and become clearly ataxic and paretic in the hind limbs. Dystonia is also observed. Wild-type mice fed on $\alpha$ tocopherol-deficient diet do not differ significantly from wild-type mice on a normal diet [71].

Clk-1 gene encodes a demethoxyubiquinone hydroxylase catalyzing the production of coenzyme Q (CoQ) in mitochondria [60]. Clk-1 mutants of yeasts, nematodes, and mice cannot synthesize CoQ, but instead accumulate DMQ [60, 62, 63]. Clk-1-deficient mice lacking CoQ fail to survive beyond the embryonic day 10.5. Mouse coq7 gene is homologous to Saccharomyces cerevisiae coq7/cat 5 and is necessary for biosynthesis of CoQ. COQ7-deficient mouse shows a small-size body and delayed embryogenesis. Morphological studies reveal a failure in the radial arrangement in the developing cerebral wall. Dietary $\mathrm{CoQ}$ tests in Drosophila melanogaster does not increase life span or decrease age-dependent decline in cytochrome c oxidase activity.

A mutant $B A L B / c$ mouse strain represents an interesting model for Niemann-Pick disease (NPC). This model displays a biochemical phenotype similar to patients with NPC1 disease, including neurodegeneration [79], irregular dendritic trees and spines [160], and progressive tauopathy $[161,162]$. The amount of cholesterol within mitochondria membranes is significantly elevated in NPC1 mouse brains and neural cells. In addition, the mitochondrial membrane potential, the activity of ATP synthase, and the level of ATP are markedly decreased in NPC1 mouse brains and neurons. NPC1 neurons show an impaired neurite outgrowth, which can be rescued by exogenous ATP. Two $C$. elegans homologs of the human NPC1 gene, designated $n p c-1$ and $n p c-2$, have been generated to assess mechanisms underlying Niemann-Pick disease [80]. Mutant animals for $n p c-1$ develop slowly, laid eggs prematurely, and are hypersensitive to cholesterol deprivation. These phenotypes in C. elegans provide a model system for both genetic and chemical suppressor screening that could identify promising drugs.

The Phyh knockout mouse has been generated to study Refsum's disease. Toxicity of high phytanic acid levels has been confirmed in different tissues of this model. Phy $h^{-/-}$ mice under a $0.25 \%$ phytol diet show liver steatosis and hepatocytes degeneration. Phytol causes an increase in plasma levels of alanine-amino transferase and amylase, indicative of liver and pancreas damage [74]. Phenotypically the $P h y h^{-/-}$mice show an abnormal gait when supplements of phytol are administered. The toe spread, paw print area, and base of support of the hindpaws are decreased, leading to an unsteady gait, explained in particular by a denervation of intrinsic foot muscles and a peripheral neuropathy. Histochemical analysis in the cerebellum reveals a loss of Purkinje cells. Furthermore, astrocytosis in the inferior colliculus, thalamus, and cerebellum are observed.

Jittery is a spontaneous autosomal recessive mouse mutation which arose around 1935 during the process of maintaining the mouse strain Bagg albino [163], which later became BALB/c [68]. Mice homozygous for the jittery mutation exhibit severe trunk and limb ataxia. They die of dehydration and starvation by 3-4 weeks of age [164]. Jittery is caused by a mutagenic B1 insertion into exon 4 of the Atcay gene [69]. The locus on 19p13.3 associated with Cayman ataxia might be homologous to the locus on mouse chromosome 10 associated with the recessive ataxic mouse jittery [69].

A neurologic disorder with clinical, morphologic, biochemical, and genetic similarities to human GM1 gangliosidosis has been discovered in two families of Siamese cats and in one isolated case of a short-hair domestic cat [81]. Affected kittens develop progressive tremors of head and pelvic limbs, generalized dysmetria, which advances to spastic quadriplegia. Additional symptoms are exaggerated acousticomotor responses, impaired vision, and grand mal seizures. This model is of interest in testing potential therapeutic strategies. GM1 gangliosidosis has also been identified in cattle [82], dogs [164, 165], and sheep [166]. Animals are clinically similar to the juvenile (type 2) form of the disease in humans [167]. Interestingly, the GM1 English Springer Spaniel (ESS) and Portuguese Water Dog, unlike other animal models for GM1 gangliosidosis, are characterized by skeletal lesions [168]. The two models 
have similar age of onset, organ involvement, bone dysplasia, residual enzyme activity, and lymphocyte vacuolation, but they differ in the visceral storage of glycoproteins containing polylactosaminoglycans [169], as well as in the presence of coarse facial features, noted only in the ESS model [170]. The urine of both dog models contains a protein activator that stimulates the conversion of GM1 ganglioside to GM2 [171]. A mouse model lacking a functional beta-galactosidase gene has been generated by homologous recombination and embryonic stem cell technology. Tissues are deficient in beta-galactosidase mRNA and GM1 ganglioside-hydrolyzing capacity. The feline Korat model for GM2 gangliosidosis is deficient in hexosaminidase $\mathrm{A}$ and $\mathrm{B}$ activity. Korat cats show a phenotype analogous to human Sandhoff's disease. Postmortem studies show hepatomegaly and typical storage vacuoles. A murine model of Tay-Sachs disease, the prototype of the GM2 gangliosidoses, has been produced through the targeted disruption of the Hexa gene encoding the subunit of alpha-hexosaminidase A $\left(\mathrm{Hexa}^{-/}\right)$mice. The mice accumulate GM2 gangliosides in the CNS and membranous cytoplasmic bodies are also found in the brain. The difference in the distribution of storage neurons suggests a distinct metabolism of gangliosides between humans and mice. Similar to the $\mathrm{Hexa}^{-/-}$mice, the $\mathrm{Gm} 2 \mathrm{a}^{-/-}$ mice demonstrate storage in restricted regions of the brain. However, they show abnormal storage in the cerebellum and develop deficits in balance and motor coordination.

Wilson's disease is a severe human disorder of copper homoeostasis. The disease is associated with various mutations in the ATP7B gene that encodes a coppertransporting ATPase. The $L E C$ rat is a mutant inbred strain, which was established from a closed colony of randomly bred Long-Evans rats [82]. This mutant has a deletion in the copper transporting ATPase gene (Atp 7b) [172]. LEC rats show elevated copper levels in liver, defective incorporation of copper into ceruloplasmin, and reduced biliary excretion of copper [173]. They also show similarities to Wilson's disease in many clinical and biochemical features [174]. They develop intravascular hemolysis secondary to the release of large amounts of nonceruloplasmin copper into the bloodstream [175]. They are also highly susceptible to the development of hepatocellular carcinoma [176]. Another model is the toxic milk (tx) mouse, associated with an autosomal recessive mutation impairing copper homeostasis [177]. Offspring of mutant females are born copper-deficient and since their mother's milk is also low in copper, babies die. They present liver nodular fibrosis, bile duct hyperplasia, and portal lymphocytic inflammatory cell infiltration [178]. Toxic milk mice share several biochemical abnormalities with Wilson's disease. The $a t p 7 b^{-/-}$mice also display a gradual accumulation of hepatic copper. Progeny of the homozygous mutant females demonstrate neurological abnormalities and growth retardation suggestive of copper deficiency.

The heterozygous mutant Apob allele mouse (Apob83) in which apoB100 amino acid 3798 has been changed to a stop codon shows a phenotype strikingly similar to the familial abetalipoproteinemia. In both human and mouse "apoB83 heterozygotes", plasma concentrations of apoB83 are extremely low. The apoB83 in the plasma is confined to the most buoyant very low density lipoprotein particles. When compared with a wild-type Apob allele, the Apob83 allele is associated with low levels of the apoB mRNA. ApoB synthesis and secretion are defective. Furthermore, apoB83 is cleared from the plasma extremely rapidly $[72,73]$.

A homozygous knock-in mouse expressing a proofreading-deficient version of PolgA (D257A mice), the nucleus-encoded catalytic subunit of mtDNA polymerase, has been generated to study mitochondrial disorders [65, 178, 179]. The knock-in mice develop a mtDNA mutator phenotype with an increase in the levels of point mutations, as well as increased amounts of deleted mtDNA. This increase is associated with reduced life span, weight loss, reduced subcutaneous fat, alopecia, kyphosis, osteoporosis, anemia, reduced fertility, and heart enlargement. Another model of these disorders is the transgenic mouse, in which mutant POLG is expressed in a neuron-specific manner. The mice show forebrain-specific defects of mtDNA and have altered monoaminergic functions in the brain. They exhibit a distorted day-night rhythm and a robust periodic activity pattern associated with estrous cycle [180].

To establish a direct in vivo link between endoplasmic reticulum (ER) dysfunction and neurodegeneration, a homozygous mouse with respect to the woozy (wz) mutation was created. The model develops adult-onset ataxia with cerebellar Purkinje cell loss. Interestingly, the wz mutation disrupts the gene Sill that encodes an adenine nucleotide exchange factor of BiP, a crucial ER chaperone. These findings provide evidence that a perturbation of ER chaperone function in terminally differentiated neurons leads to protein accumulation, ER stress, and subsequent neurodegeneration [64]. A recessive mouse mutation, tumbler $(t b)$, was previously mapped to chromosome 1 by linkage [67]. $\mathrm{Tb}$ mice show ataxia, walking in a crab-like fashion and falling. Engert et al. have speculated that these mice harbored a mutation in Sacs gene [66].

Accordingly to the biochemical deficit in human, neuronal storage of SGalCer has been observed in arylsulfatase A $\left(A S A^{-/-}\right)$mice $[77,78]$. These mice accumulate sulfolipids not only in neurons, microglia, and other glial cells but also in nonneural tissues, including kidney and gallbladder [181, 182]. However, the mice accumulate less sulfatides than in humans and do not show 
demyelination. The mild phenotype of these mice offers the opportunity to investigate the consequences of lipid storage in particular cell types. The transgenic $A S A^{-/-}$mice are related to the enzymes catalyzing the synthesis of SGalCer in neurons: (1) uridine diphosphate-galactose/ceramide galactosyltransferase (CGT) [183] and (2) the 3'-phosphoadenosine-5'-phosphosulfate/cerebroside sulfotransferase (CST) [76]. The phenotype presents with accumulation of SGalCer, ataxia, and nerve fiber degeneration in the spinal cord.

To elucidate the role of ceruloplasmin in iron homeostasis, an animal model of aceruloplasminemia has been generated by disrupting the homolog murine $C p$ gene [83]. Although normal at birth, $C p^{-/-}$mice demonstrate progressive accumulation of iron. Histologic analysis show abundant iron stores within reticuloendothelial cells and hepatocytes. Ferrokinetic studies reveal normal iron absorption and plasma iron turnover, suggesting that iron accumulation results from altered compartmentalization within the iron cycle. Accordingly, $C p^{-/}$mice show a striking impairment in the movement of iron out of reticuloendothelial cells and hepatocytes. Retinas studies have shown that mice deficient in both $\mathrm{Cp}$ and Heph have a striking age-dependent increase in iron. The iron storage protein ferritin is also increased in the doubly null retinas [184].

A murine model of ataxia telangiectasia by disrupting the Atm $\left[\mathrm{atm}^{-/}\right]$locus via gene targeting is available [85]. Homozygous mice display growth retardation, neurologic dysfunction, absence of mature gametes, infertility, defects in $\mathrm{T}$ lymphocyte maturation, and extreme sensitivity to gamma-irradiation. Animals develop malignant thymic lymphomas. Atm-disrupted mice recapitulate the ataxia telangiectasia phenotype in humans. In contrast to other Atm mutant mice, the Atm $y / y$ mice show a lower incidence of thymic lymphoma and survive beyond a few months of age. They exhibit deficits in motor learning indicative of cerebellar dysfunction. No cerebellar degeneration is observed [84].

\section{Models of X-Linked Ataxias}

The knockout mice lacking normal FMR1 $\left(f m r 1^{-/-}\right)$protein show macroorchidism, learning deficits, and hyperactivity. The mice do not show the specific brain structures abnormalities observed in human [86]. Presumably, the dendritic spines fail to assume a normal mature size and shape. Normal dendritic regression is also impaired [185]. However, unlike in human, the knockout mice do not show statistically significant dendritic spine density [186]. Amount of dense granules are low and metabotropic GluR5 (GRM5)-induced translation is increased [87]. Animals have deficits in classic delay eyeblink conditioning and cerebellar Purkinje cells showed elongated irregular dendritic spines, with enhanced long-term depression induction at the parallel fiber synapses that innervate these spines [187]. The yeast artificial chromosome (YAC) transgenic mice have been created to determine whether the $f m r 1^{-/}$ mouse phenotype could be rescued. The YAC transgene is expressed in cell- and tissue-specific manner [188]. A Drosophila model using loss-of-function mutants and overexpression of the FMR1 homolog, dfxr (Drosophila fragile X-related gene), has also been developed [189]. Dfxr nulls display enlarged synaptic terminals, whereas neuronal overexpression result in fewer and larger synaptic boutons. Synaptic structural defects are accompanied by impaired neurotransmission.

The transgenic mouse with an expanded CGG repeat (102/110 repeats) in human FMR1 has elevated fmrl mRNA levels and intranuclear inclusions with ubiquitin, Hsp40, and the 20S catalytic core complex of the proteasome as constituents. Both the number and the size of the inclusions are increased during the course of life, which correlate with the progressive character of the cerebellar tremor/ataxia syndrome in humans [88]. Human FMR1 premutated allele of 90 CGG repeats has been expressed in Drosophila [89]. The expanded RNA induces neuron-specific degeneration. Microarray analysis detects an altered expression of CASP8, CYFIP1, NTS, and UBE3A.

A mouse model of adrenoleukodystrophy (ALD) by targeted disruption has been generated [90]. Older Aldpdeficient mice exhibit an abnormal neurologic and behavioral phenotype, starting at around 15 months of age. This is correlated with slower nerve conduction and with myelin/ axonal anomalies detectable in the spinal cord and sciatic nerve, but not in brain [190, 191]. Axonal damage is the first pathologic event in the $A b c d l^{-/-}$mice. Interestingly, overexpression of $A b c d 2$ prevents both very long chain fatty acids (VLCFA) accumulation and neurodegenerative features, whereas $A b c d 1 / A b c d 2$ double mutants exhibit an earlier onset of symptoms and a more severe disease [192]. The Drosophila recessive mutant bubblegum (bgm) shows adult neurodegeneration, with marked dilation of photoreceptor axons. This mutant has elevated levels of VLCFAs, as seen in ALD [91].

MECP2 mutation in Rett syndrome fits with the mecp2 deficiency in mice [92]. Mecp2 mice (mecp $2^{-1-}$ ) phenotypic manifestations include nervousness, body trembling, piloerection, and occasional hard respiration. At late stages, mutants become hypoactive. Heterozygous mutant females show symptoms at a late age: weight gain, reduced activity, and ataxic gait. A substantial reduction in both brain weight and neuronal cell size can be observed [93]. A model with replaced exons 3 and 4 of MECP2 is also available. Mice are viable and fertile. Mice overexpressing wild-type 
human MECP2 [193] display enhanced motor/contextual learning and enhanced synaptic plasticity in the hippocampus. After 20 weeks of age, mice developed seizures, hypoactivity, and spasticity.

\section{Models of Sporadic Ataxias}

Sporadic cerebellar ataxias are also the cause of a substantial degree of morbidity worldwide. A typical example is the disability resulting from traumatic brain injury (TBI) [194]. Neurological deficits may result from a direct or indirect cerebellar injury. Limb or trunk ataxia, tremor, speech difficulties, and cognitive deficits are common in patients with TBI $[195,196]$. Cerebellar deficits may be delayed [197]. Cerebellum is often affected even when the initial injury does not directly involve its components [198]. In this issue, Potts and colleagues discuss the mechanisms of TBI. We have gained insights into the understanding of cerebellar damage thanks to experimental models of TBI, namely fluid percussion injury (FPI), controlled cortical impact injury (CCI), weight drop impact acceleration injury, and rotational acceleration injury. In FPI, a pendulum strikes a fluid-filled piston which transmits a fluid pulse to the surface of the brain. This generates both a focal and diffuse injury, including a cerebral contusion and subarachnoid hemorrhage at the site of impact as well as more diffuse neuronal loss within the ipsilateral hippocampus, thalamus, striatum, amygdala, and medial septum [199]. In CCI, the injury is generated when an electronically controlled piston hits the surface of the brain. The severity of the injury is determined by the height from which the pendulum is dropped. Interestingly, the pathology of injury in the cerebellum after CCI is similar to that resulting from FPI, including Purkinje cell loss and microglial activation [96]. Several studies based on those models have shown that the cerebellar vermis is particularly sensitive to trauma. The weight drop impact acceleration injury induces a more diffuse TBI by delivering a force to the intact skull as opposed to the exposed brain [200]. A rotational component is produced when the head is displaced upon impact. A decreased expression of nitric oxide metabolites has been reported a few minutes after injury, suggesting a relationship to decreased blood flow after TBI [201]. Rotational acceleration injury mimics a rotational force against the brain and is characterized by diffuse subarachnoid hemorrhage, cortical hemorrhages, and astrogliosis [202]. Brain edema and an excitotoxic cascade result in extensive delayed neuronal cell death by apoptotic necrosis in several regions including the cerebellum [203]. Other authors have used a direct cerebellar trauma. FPI applied over the posterior fossa has been associated with impaired excitability of mossy fibers and parallel fibers, contributing to Purkinje cell death [204].
Information provided by these models are complementary to those gained from experiments based on axotomy or stab injury [205, 206]. These last models have provided interesting information regarding the discrepancies between Purkinje neurons and climbing fibers in terms of capacity of regeneration in an appropriate environment [207, 208].

Remote damage is not uncommon in cerebellar ataxias. Several factors contribute to the severity of remote cell death, mainly the type and extent of the primary insult, the characteristics of the connectivity, and the intrinsic vulnerability of the circuits [209]. Targeting the mechanisms of remote lesions has become a therapeutic strategy per se. Viscomi et al. have analyzed the degenerative mechanisms in the inferior olive and pontine nuclei after focal cerebellar lesion [210]. The authors have investigated the schedule of neuronal death in olivary and pontine neurons following hemicerebellectomy [211]. Time course of neuronal loss is distinct in the two populations. After hemicerebellectomy, precerebellar nuclei show a significant astrocytic and microglial activation [211]. Glial activation reaches a peak about 3 weeks after ablation of the hemicerebellum. Glial reaction is accompanied by a strong induction of the cytokine interleukin (IL)-1 $\beta$, a mediator which is known to enhance neuronal damage [212]. High doses of methylprednisolone improve neuronal survival in precerebellar nuclei and decrease the levels of IL-1 $\beta$. Although minocycline-which modulates microgliosis and inhibits caspase protease expression - inhibits microglial activation, there is no beneficial effect in terms of neuronal survival in the precerebellar nuclei. Other groups have reached similar conclusions [213].

There are numerous studies focusing on the vulnerability of the cerebellum to toxic agents [214, 215]. Cerebellar ataxia is classically observed in acute or chronic intoxication to ethanol [25]. Cerebellar degeneration contributes to motor and neuropsychological deficits in chronic alcoholics and in children with prenatal ethanol exposure. The mechanisms underlying these ethanol-induced alterations include excitotoxicity, dietary factors - especially thiamine depletion-glial dysfunction, changes in growth factors, apoptotic mechanisms, and various degrees of oxidative stress. Most of these mechanisms have been unraveled thanks to animal studies based on ethanol exposure, in addition to cell cultures [216, 217]. One model of cerebellotoxicity addresses the acute demyelination induced by cuprizone [218]. The model of cuprizone-induced toxicity reproduces several features of cerebellar deep gray matter observed in demyelinating disorders like multiple sclerosis (MS), a common disorder which affects the cerebellum frequently. Because ataxic deficits in MS significantly contribute to disability and are relatively refractory to therapy, there is a need to extend research beyond the classical models experimental such as autoim- 
mune encephalomyelitis (EAE) [219]. Cuprizone is especially toxic for oligodendrocytes $[220,221]$. The superior cerebellar peduncle is a main target [222]. Groebe and colleagues show that cerebellar nuclei show an intense demyelination. The white matter of the cerebellar cortex presents a swelling of myelin sheath. The authors also show that cuprizone induces an astroglial proliferation and migration toward the injured area. Astrocytes secrete several cytokines such as tumor necrosis factor- $\alpha$ or interleukin $1-\beta$ as well as proinflammatory prostaglandins, which likely participate in oligodendrocyte damage [223, 224]. Other neurotoxins widely used to reproduce human disorders include harmaline and other beta-carboline alkaloids for the investigation of tremor [94, 225, 226] and exposure to heavy metals which are known the target the cerebellar circuits among others [227, 228].

Appealing data on the roles of hormones in cerebellar development have been published recently $[229,230]$. The importance of hormonal signaling on the numerous cerebellar functions has been highlighted [231, 232]. Animal models such as congenital hypothyroid animals due to thyroid gland dysgenesis or thyroid dyshormonogenesis, thyroid hormone receptor (TR) gene-mutated animals, and thyroid hormone transport or metabolism-modified animals are representative [97, 233, 234]. The brain itself has the capability of forming steroids de novo from cholesterol $[235,236]$. Studies on mammals and nonmammals indicate that this neurosteroidogenesis is a conserved property of vertebrates [237]. In mammals, Purkinje cells differentiate just after birth and the formation of cerebellar neuronal circuit becomes complete in the neonate, when the formation of progesterone and estradiol are high. These hormones promote dendritic growth, spinogenesis, and synaptogenesis [237]. Discoveries of hormonal receptors are providing a possible explanation for the link between hormonal defects and ataxias such as Boucher-Neuhauser syndrome or Holmes syndrome [238, 239].

As man embarks on space exploration with the objective of space habitation, the need to understand the impact of gravity is obvious [240]. Many symptoms observed in astronauts are indicative of a vestibular dysfunction. Animal studies support the idea of an effect of altered gravity on CNS functions. However, our knowledge of the consequences of altered gravity on the vestibulocerebellar system is just starting to grow. Developmental sensitivity of the vestibuloocular reflex to hypergravity has been studied in amphibians; fish and insects (lacking a vestibular system) are an example of the complexity of the interactions between altered gravity and timing of vulnerability [241, 242].

In conclusion, a survey of the literature of these last two decades highlights the increasing number of animal models of cerebellar ataxias. In particular, genetically engineered animals and animals with spontaneous mutations have entered in the routine analysis in many laboratories. These investigations are complementary to the studies carried in human disorders and speed up the discovery of the physiology of the cerebellum [243], the mechanisms of diseases as well as the search for effective therapies. The question of the characterization and relevance of these models should not be underestimated. Morphological differences across species may be marked or subtile and probably meaningless $[244,245]$. Future therapies such as application of viral vectors to rescue genes in knockout mice will benefit from a detailed evaluation of the models considered [246, 247]

Acknowledgments M.M. is supported by the FNRS-Belgium; D.M. is supported by the Fonds Erasme-Belgium.

\section{References}

1. Manto M (2008) The cerebellum, cerebellar disorders, and cerebellar research - two centuries of discoveries. Cerebellum 7 (4):505-516

2. Underwood BR, Rubinsztein DC (2008) Spinocerebellar ataxias caused by polyglutamine expansions: a review of therapeutic strategies. Cerebellum 7(2):215-221

3. Klockgether T (2007) Ataxias. Parkinsonism Relat Disord 13 (Suppl 3):S391-S394

4. Klockgether $\mathrm{T}$ (2008) The clinical diagnosis of autosomal dominant spinocerebellar ataxias. Cerebellum 7(2):101-105

5. Thoma P, Bellebaum C, Koch B, Schwarz M, Daum I (2008) The cerebellum is involved in reward-based reversal learning. Cerebellum 7(3):433-443

6. Strick PL, Dum RP, Fiez JA (2009) Cerebellum and nonmotor function. Annu Rev Neurosci 32:413-434

7. Leggio MG, Tedesco AM, Chiricozzi FR, Clausi S, Orsini A, Molinari M (2008) Cognitive sequencing impairment in patients with focal or atrophic cerebellar damage. Brain 131(Pt 5):13321343

8. Timmann D, Daum I (2007) Cerebellar contributions to cognitive functions: a progress report after two decades of research. Cerebellum 6(3):159-162

9. Shatunov A, Fridman EA, Pagan FI, Leib J, Singleton A, Hallett M, Goldfarb LG (2004) Small de novo duplication in the repeat region of the TATA-box-binding protein gene manifest with a phenotype similar to variant Creutzfeldt-Jakob disease. Clin Genet 66(6):496-501

10. Bürk K (2007) Cognition in hereditary ataxia. Cerebellum 6 (3):280-286

11. Matilla-Dueñas A (2008) The highly heterogeneous spinocerebellar ataxias: from genes to targets for therapeutic intervention. Cerebellum 7(2):97-100

12. Jen JC (2008) Hereditary episodic ataxias. Ann N Y Acad Sci 1142:250-253

13. Matilla-Dueñas A, Goold R, Giunti P (2008) Clinical, genetic, molecular, and pathophysiological insights into spinocerebellar ataxia type 1 . Cerebellum 7(2):106-114

14. Dueñas AM, Goold R, Giunti P (2006) Molecular pathogenesis of spinocerebellar ataxias. Brain 129(Pt 6):1357-1370

15. Manto M, Marmolino D (2009) Cerebellar ataxias. Curr Opin Neurol 22(4):419-429 
16. Katsuno M, Banno H, Suzuki K, Takeuchi Y, Kawashima M, Tanaka F, Adachi H, Sobue G (2008) Molecular genetics and biomarkers of polyglutamine diseases. Curr Mol Med 8(3):221234

17. Costa Lima MA, Pimentel MM (2004) Dynamic mutation and human disorders: the spinocerebellar ataxias. Int J Mol Med 13 (2):299-302

18. Ikeda Y, Daughters RS, Ranum LP (2008) Bidirectional expression of the SCA8 expansion mutation: one mutation, two genes. Cerebellum 7(2):150-158

19. Gupta A, Jankovic J (2009) Spinocerebellar ataxia 8: variable phenotype and unique pathogenesis. Parkinsonism Relat Disord (in press)

20. Iwata A, Christianson JC, Bucci M, Ellerby LM, Nukina N, Forno LS, Kopito RR (2005) Increased susceptibility of cytoplasmic over nuclear polyglutamine aggregates to autophagic degradation. Proc Natl Acad Sci U S A 102(37):1313513140

21. Wakamiya M, Matsuura T, Liu Y, Schuster GC, Gao R, Xu W, Sarkar PS, Lin X, Ashizawa T (2006) The role of ataxin 10 in the pathogenesis of spinocerebellar ataxia type 10. Neurology 67 (4):607-613

22. Brusse E, Maat-Kievit JA, van Swieten JC (2007) Diagnosis and management of early- and late-onset cerebellar ataxia. Clin Genet 71(1):12-24

23. Tsuji S, Onodera O, Goto J, Nishizawa M, Study Group on Ataxic Diseases (2008) Sporadic ataxias in Japan - a populationbased epidemiological study. Cerebellum 7(2):189-197

24. Gilman S, Wenning GK, Low PA, Brooks DJ, Mathias CJ, Trojanowski JQ, Wood NW, Colosimo C, Dürr A, Fowler CJ, Kaufmann H, Klockgether T, Lees A, Poewe W, Quinn N, Revesz T, Robertson D, Sandroni P, Seppi K, Vidailhet M (2008) Second consensus statement on the diagnosis of multiple system atrophy. Neurology 71(9):670-676

25. Jaatinen P, Rintala J (2008) Mechanisms of ethanol-induced degeneration in the developing, mature, and aging cerebellum. Cerebellum 7(3):332-347

26. Vonghia L, Leggio L, Ferrulli A, Bertini M, Gasbarrini G, Addolorato G, Alcoholism Treatment Study Group (2008) Acute alcohol intoxication. Eur J Intern Med 19(8):561-567

27. Hadjivassiliou M, Sanders DS, Woodroofe N, Williamson C, Grünewald RA (2008) Gluten ataxia. Cerebellum 7(3):494-498

28. Nanri K, Okita M, Takeguchi M, Taguchi T, Ishiko T, Saito H, Otsuka T, Mitoma H, Koizumi K (2009) Intravenous immunoglobulin therapy for autoantibody-positive cerebellar ataxia. Intern Med 48(10):783-790

29. Watase K, Weeber EJ, Xu B, Antalffy B, Yuva-Paylor L, Hashimoto $\mathrm{K}$ et al (2002) A long CAG repeat in the mouse Scal locus replicates SCA1 features and reveals the impact of protein solubility on selective neurodegeneration. Neuron 34:905-919

30. Zu T, Duvick LA, Kaytor MD, Berlinger MS, Zoghbi HY, Clark $\mathrm{HB}$ et al (2004) Recovery from polyglutamine-induced neurodegeneration in conditional SCA1 transgenic mice. J Neurosci 24:8853-8861

31. Cummings CJ, Mancini MA, Antalffy B, DeFranco DB, Orr HT, Zoghbi HY (1998) Chaperone suppression of aggregation and altered subcellular proteasome localization imply protein misfolding in SCA1. Nat Genet 19:148-154

32. Clark HB, Burright EN, Yunis WS, Larson S, Wilcox C, Hartman B et al (1997) Purkinje cell expression of a mutant allele of SCA1 in transgenic mice leads to disparate effects on motor behaviors, followed by a progressive cerebellar dysfunction and histological alterations. J Neurosci 17:7385-7395

33. Burright EN, Clark HB, Servadio A, Matilla T, Feddersen RM, Yunis WS et al (1995) SCA1 transgenic mice: a model for neurodegeneration caused by an expanded CAG trinucleotide repeat. Cell 82:937-948

34. Huynh DP, Figueroa K, Hoang N, Pulst SM (2000) Nuclear localization or inclusion body formation of ataxin-2 are not necessary for SCA2 pathogenesis in mouse or human. Nat Genet 26:44-50

35. Cemal CK, Carroll CJ, Lawrence L, Lowrie MB, Ruddle P, AlMahdawi $S$ et al (2002) YAC transgenic mice carrying pathological alleles of the MJD1 locus exhibit a mild and slowly progressive cerebellar deficit. Hum Mol Genet 11:1075-1094

36. Goti D, Katzen SM, Mez J, Kurtis N, Kiluk J, Ben-Haïem L et al (2004) A mutant ataxin-3 putative-cleavage fragment in brain of Machado-Joseph disease patients and transgenic mice is cytotoxic above a critical concentration. J Neurosci 24:10266-10279

37. Fletcher CF, Lutz CM, O'Sullivan TN, Shaughnessy JD, Hawkes R, Frankel WN, Copeland NG, Jenkins NA (1996) Absence epilepsy in tottering mutant mice is associated with calcium channel defects. Cell 87:607-617

38. van den Maagdenberg AM, Pietrobon D, Pizzorusso T, Kaja S, Broos LA, Cesetti T, van de Ven RC, Tottene A, van der Kaa J, Plomp JJ, Frants RR, Ferrari MD (2004) A Cacnala knockin migraine mouse model with increased susceptibility to cortical spreading depression. Neuron 41:701-710

39. Watase $\mathrm{K}$, Barrett $\mathrm{CF}$, Miyazaki $\mathrm{T}$, Ishiguro $\mathrm{T}$, Ishikawa $\mathrm{K}, \mathrm{Hu} \mathrm{Y}$, Unno T, Sun Y, Kasai S, Watanabe M, Gomez CM, Mizusawa H, Tsien RW, Zoghbi HY (2008) Spinocerebellar ataxia type 6 knockin mice develop a progressive neuronal dysfunction with age-dependent accumulation of mutant $\mathrm{Ca}(\mathrm{v}) 2.1$ channels. Proc Nat Acad Sci U S A 105:11987-11992

40. Yoo SY, Pennesi ME, Weeber EJ, Xu B, Atkinson R, Chen S et al (2003) SCA7 knockin mice model human SCA7 and reveal gradual accumulation of mutant ataxin-7 in neurons and abnormalities in short-term plasticity. Neuron 37:383-401

41. Yvert G, Lindenberg KS, Picaud S, Landwehrmeyer GB, Sahel JA, Mandel JL (2000) Expanded polyglutamines induce neurodegeneration and trans-neuronal alterations in cerebellum and retina of SCA7 transgenic mice. Hum Mol Genet 9:2491-2506

42. Garden GA, Libby RT, Fu YH, Kinoshita Y, Huang J, Possin DE et al (2002) Polyglutamine-expanded ataxin-7 promotes non-cell-autonomous Purkinje cell degeneration and displays proteolytic cleavage in ataxic transgenic mice. J Neurosci 22:4897-4905

43. Moseley ML, Zu T, Ikeda Y, Gao W, Mosemiller AK, Daughters RS, Chen G, Weatherspoon MR, Clark HB, Ebner TJ, Day JW, Ranum LP (2006) Bidirectional expression of CUG and CAG expansion transcripts and intranuclear polyglutamine inclusions in spinocerebellar ataxia type 8. Nature Genet 38:758-769

44. He Y, Zu T, Benzow KA, Orr HT, Clark HB, Koob MD (2006) Targeted deletion of a single Sca8 ataxia locus allele in mice causes abnormal gait, progressive loss of motor coordination, and Purkinje cell dendritic deficits. J Neurosci 26(39):99759982

45. Cogram P, Hynes A, Dunlevy LP, Greene ND, Copp AJ (2004) Specific isoforms of protein kinase $\mathrm{C}$ are essential for prevention of folate-resistant neural tube defects byinositol. Hum Mol Genet $13: 7-14$

46. van de Leemput J, Chandran J, Knight MA, Holtzclaw LA, Scholz S, Cookson MR, Houlden H, Gwinn-Hardy K, Fung HC, Lin X, Hernandez D, Simon-Sanchez J, Wood NW, Giunti P, Rafferty I, Hardy J, Storey E, Gardner RJ, Forrest SM, Fisher EM, Russell JT, Cai H, Singleton AB (2007) Deletion at ITPR1 underlies ataxia in mice and spinocerebellar ataxia 15 in humans. PLoS Genet 3:e108

47. Veenstra GJC, Weeks DL, Wolffe AP (2000) Distinct roles for TBP and TBP-like factor in early embryonic gene transcription in Xenopus. Science 290:2312-2314 
48. Friedman MJ, Shah AG, Fang ZH, Ward EG, Warren ST, Li S, Li XJ (2007) Polyglutamine domain modulates the TBP-TFIIB interaction: implications for its normal function and neurodegeneration. Nat Neurosci 10(12):1519-1528

49. Hobbs NK, Bondareva AA, Barnett S, Capecchi MR, Schmidt EE (2002) Removing the vertebrate-specific TBP N terminus disrupts placental beta-2M-dependent interactions with the maternal immune system. Cell 110:43-54

50. Martianov I, Viville S, Davidson I (2002) RNA polymerase II transcription in murine cells lacking the TATA binding protein. Science 298:1036-1039

51. Sato T, Miura M, Yamada M, Yoshida T, Wood JD, Yazawa I, Masuda M, Suzuki T, Shin RM, Yau HJ, Liu FC, Shimohata T, Onodera O, Ross CA, Katsuki M, Takahashi H, Kano M, Aosaki T, Tsuji S (2009) Severe neurological phenotypes of Q129 DRPLA transgenic mice serendipitously created by en masse expansion of CAG repeats in Q76 DRPLA mice. Hum Mol Genet 18(4):723-736

52. Sato T, Oyake M, Nakamura K, Nakao K, Fukusima Y, Onodera O, Igarashi S, Takano H, Kikugawa K, Ishida Y, Shimohata T, Koide R, Ikeuchi T, Tanaka H, Futamura N, Matsumura R, Takayanagi T, Tanaka F, Sobue G, Komure O, Takahashi M, Sano A, Ichikawa Y, Goto J, Kanazawa I et al (1999) Transgenic mice harboring a full-length human mutant DRPLA gene exhibit age-dependent intergenerational and somatic instabilities of CAG repeats comparable with those in DRPLA patients. Hum Mol Genet 8:99-106

53. Cossee M, Puccio H, Gansmuller A, Koutnikova H, Dierich A, LeMeur M, Fischbeck K, Dollé P, Koenig M (2000) Inactivation of the Friedreich ataxiamouse gene leads to early embryoniclethality without iron accumulation. Hum Mol Genet 9:1219-1226

54. Puccio H, Simon D, Cossée M, Criqui-Filipe P, Tiziano F, Melki J, Hindelang C, Matyas R, Rustin P, Koenig M (2001) Mouse models for Friedreich ataxia exhibit cardiomyopathy, sensory nerve defect and $\mathrm{Fe}-\mathrm{S}$ enzyme deficiency followed by intramitochondrial iron deposits. Nat Genet 27:181-186

55. Seznec H, Simon D, Bouton C, Reutenauer L, Hertzog A, Golik P, Procaccio V, Patel M, Drapier JC, Koenig M, Puccio H (2005) Friedreich ataxia: the oxidative stress paradox. Hum Mol Genet 14:463-474

56. Simon D, Seznec H, Gansmuller A, Carelle N, Weber P, Metzger D, Rustin P, Koenig M, Puccio H (2004) Friedreich ataxia mouse models with progressive cerebellar and sensory ataxia reveal autophagic neurodegeneration in dorsal root ganglia. J Neurosci 24:1987-1995

57. Ventura N, Rea S, Henderson ST, Condo I, Johnson TE, Testi R (2005) Reduced expression of frataxin extends the lifespan of Caenorhabditis elegans. Aging Cell 4:109-112

58. Vazquez-Manrique RP, Gonzalez-Cabo P, Ros S, Aziz H, Baylis HA, Palau F (2006) Reduction of Caenorhabditis elegans frataxin increases sensitivity to oxidative stress, reduces lifespan, and causes lethality in a mitochondrial complex II mutant. FASEB J 20:172-174

59. Anderson PR, Kirby K, Hilliker AJ, Phillips JP (2005) RNAimediated suppression of the mitochondrial iron chaperone, frataxin, in Drosophila. Hum Mol Genet 14:3397-3405

60. Marbois BN, Clarke CF (1996) The COQ7 gene encodes a protein in Saccharomyces cerevisiae necessary for ubiquinone biosynthesis. J Biol Chem 271:2995-3004

61. Jonassen T, Larsen PL, Clarke CF (2001) A dietary source of coenzyme $\mathrm{Q}$ is essential for growth of long-lived Caenorhabditis elegans clk-1 mutants. Proc Natl Acad Sci U S A 98:421-426

62. Nakai D, Yuasa S, Takahashi M et al (2001) Mouse homologue of coq7/ clk-1, longevity gene in Caenorhabditis elegans, is essential for coenzyme Q synthesis, maintenance of mitochondrial integrity, and neurogenesis. Biochem Biophys Res Commun 289:463-471
63. Levavasseur F, Miyadera H, Sirois J et al (2001) Ubiquinone is necessary for mouse embryonic development but is not essential for mitochondrial respiration. J Biol Chem 276:46160-46164

64. Dickie MM (1965) Tumbler, tb. Mouse News Lett 32:45

65. Trifunovic A, Wredenberg A, Falkenberg M, Spelbrink JN, Rovio AT, Bruder CE, Bohlooly-Y M, Gidlöf S, Oldfors A, Wibom R, Törnell J, Jacobs HT, Larsson NG (2004) Premature ageing in mice expressing defective mitochondrial DNA polymerase. Nature 429(6990):417-423

66. Engert JC, Bérubé P, Mercier J, Doré C, Lepage P, Ge B, Bouchard JP, Mathieu J, Melançon SB, Schalling M, Lander ES, Morgan K, Hudson TJ, Richter A (2000) ARSACS, a spastic ataxia common in northeastern Quebec, is caused by mutations in a new gene encoding an 11.5-kb ORF. Nature Genet 24:120-125

67. Zhao L, Longo-Guess C, Harris BS, Lee J-W, Ackerman SL (2005) Protein accumulation and neurodegeneration in the woozy mutant mouse is caused by disruption of SIL1, a cochaperone of BiP. Nature Genet 37:974-979

68. Beck JA, Lloyd S, Hafezparast M, Lennon-Pierce M, Eppig JT, Festing MF, Fisher EM (2000) Genealogies of mouse inbred strains. Nat Genet 24:23-25

69. Bomar JM, Benke PJ, Slattery EL, Puttagunta R, Taylor LP, Seong E, Nystuen A, Chen W, Albin RL, Patel PD, Kittles RA, Sheffield VC, Burmeister M (2003) Mutations in a novel gene encoding a CRAL-TRIO domain cause human Cayman ataxia and ataxia/dystonia in the jittery mouse. Nat Genet 35(3):264269

70. Jishage K, Arita M, Igarashi K, Iwata T, Watanabe M, Ogawa M, Ueda O, Kamada N, Inoue K, Arai H, Suzuki H (2001) Alphatocopherol transfer protein is important for the normal development of placental labyrinthine trophoblasts in mice. J Biol Chem 276:1669-1672

71. Yokota T, Igarashi K, Uchihara T, Jishage K, Tomita H, Inaba A, Li Y, Arita M, Suzuki H, Mizusawa H, Arai H (2001) Delayedonset ataxia in mice lacking alpha -tocopherol transfer protein: model for neuronal degeneration caused by chronic oxidative stress. Proc Natl Acad Sci U S A 98(26):15185-15190

72. Yasuhara M, Ohama T, Matsuki N, Saito H, Matsushima T, Kurokawa K, Teramoto T (1991) Deficiency of apolipoprotein B synthesis in Suncus murinus. J Biochem 110(5):751-755

73. Ohama $\mathrm{T}$, Matsuki $\mathrm{N}$, Wang $\mathrm{CH}$, Saito $\mathrm{H}$, Kinoshita $\mathrm{M}$, Tsukamoto K, Kurokawa K, Katsuragawa K, Yamanaka M, Teramoto T (1993) Characterization of serum lipoproteins from Suncus: a candidate animal model for abetalipoproteinemia. J Biochem 113(6):786-789

74. Ferdinandusse S, Zomer AW, Komen JC, van den Brink CE, Thanos M, Hamers FP, Wanders RJ, van der Saag PT, Poll-The BT, Brites P (2008) Ataxia with loss of Purkinje cells in a mouse model for Refsum disease. Proc Natl Acad Sci U S A 105 (46):17712-17717

75. Lyons MA, Maeda N, Brown AJ (2002) Paradoxical enhancement of hepatic metabolism of 7- ketocholesterol in sterol 27hydroxylase-deficient mice. Biochim Biophys Acta 1581 (3):119-126

76. Morell P, Radin NS (1969) Synthesis of cerebroside by brain from uridine diphosphate galactose and ceramide containing hydroxy fatty acid. Biochemistry 8:506-512

77. Lüllmann-Rauch R, Matzner U, Franken S, Hartmann D, Gieselmann V (2001) Lysosomal sulfoglycolipid storage in the kidneys of mice deficient for arylsulfatase A (ASA) and of double-knockout mice deficient for ASA and galactosylceramide synthase. Histochem Cell Biol 116:161-169

78. Molander-Melin M, Pernber Z, Franken S, Gieselmann V, Mansson JE, Fredman P (2004) Accumulation of sulfatide in neuronal and glial cells of arylsulfatase A deficient mice. J Neurocytol 33:417-427 
79. Morris MD, Bhuvaneswaran C, Shio H, Fowler S (1982) Lysosome lipid storage in NCTR-BALB/c mice. I. Description of the disease and genetics. Am J Pathol 108:140-149

80. Sym M, Basson M, Johnson C (2000) A model for NiemannPick type $\mathrm{C}$ disease in the nematode Caenorhabditis elegans. Curr Biol 10(9):527-530

81. Blakemore WF (1972) GM gangliosidosis in a cat. J Comp Pathol 82:179

82. Donnelly WJC, Sheahan BJ (1981) Gm1-gangliosidosis of Friesian calves. A review. Irish Vet J 35:45-55

83. Kasai N, Osanai T, Miyoshi I, Kamimura E, Yoshida MC, Dempo K (1990) Clinico-pathological studies of LEC rats with hereditary hepatitis and hepatoma in the acute phase of hepatitis. Lab Anim Sci 40:502-505

84. Harris ZL, Durley AP, Man TK, Gitlin JD (1999) Targeted gene disruption reveals an essential role for ceruloplasmin in cellular iron efflux. Proc Natl Acad Sci U S A 96(19):10812-10817

85. Borghesani PR, Alt FW, Bottaro A, Davidson L, Aksoy S, Rathbun GA, Roberts TM, Swat W, Segal RA, Gu Y (2000) Abnormal development of Purkinje cells and lymphocytes in Atm mutant mice. Proc Nat Acad Sci U S A 97:3336-3341

86. Barlow C, Eckhaus MA, Schaffer AA, Wynshaw-Boris A (1999) Atm haploinsufficiency results in increased sensitivity to sublethal doses of ionizing radiation in mice. Nature Genet 21:359-360

87. Kooy RF, Reyniers E, Verhoye M, Sijbers J, Bakker CE, Oostra BA, Willems PJ, Van Der Linden A (1999) Neuroanatomy of the fragile X knockout mouse brain studied using in vivo high resolution magnetic resonance imaging. Eur J Hum Genet 7:526-532

88. Aschrafi A, Cunningham BA, Edelman GM, Vanderklish PW (2005) The fragile $X$ mental retardation protein and group I metabotropic glutamate receptors regulate levels of mRNA granules in brain. Proc Nat Acad Sci U S A 102:2180-2185

89. Willemsen R, Hoogeveen-Westerveld M, Reis S, Holstege J, Severijnen LA, Nieuwenhuizen IM, Schrier M, van Unen L, Tassone F, Hoogeveen AT, Hagerman PJ, Mientjes EJ, Oostra BA (2003) The FMR1 CGG repeat mouse displays ubiquitinpositive intranuclear neuronal inclusions; implications for the cerebellar tremor/ataxia syndrome. Hum Mol Genet 12:949-959

90. Jin P, Zarnescu DC, Zhang F, Pearson CE, Lucchesi JC, Moses K, Warren ST (2003) RNA-mediated neurodegeneration caused by the fragile $\mathrm{X}$ premutation $\mathrm{rCGG}$ repeats in Drosophila. Neuron 39:739-747

91. Forss-Petter S, Werner H, Berger J, Lassmann H, Molzer B, Schwab MH, Bernheimer H, Zimmermann F, Nave K-A (1997) Targeted inactivation of the X-linked adrenoleukodystrophy gene in mice. J Neurosci Res 50:829-843

92. Min KT, Benzer S (1999) Preventing neurodegeneration in the Drosophila mutant bubblegum. Science 284:1985-1988

93. Tate P, Skarnes W, Bird A (1996) The methyl-CpG binding protein $\mathrm{MeCP} 2$ is essential for embryonic development in the mouse. Nature Genet 12:205

94. Young JI, Zoghbi HY (2004) X-chromosome inactivation patterns are unbalanced and affect the phenotypic outcome in a mouse model of Rett syndrome. Am J Hum Genet 74:511-520

95. Miwa H (2007) Rodent models of tremor. Cerebellum 6(1):66-72

96. Mackenzie-Graham A, Tiwari-Woodruff SK, Sharma G, Aguilar C, Vo KT, Strickland LV, Morales L, Fubara B, Martin M, Jacobs RE, Johnson GA, Toga AW, Voskuhl RR (2009) Purkinje cell loss in experimental autoimmune encephalomyelitis. Neuroimage (in press)

97. Igarashi T, Potts MB, Noble-Haeusslein LJ (2007) Injury severity determines Purkinje cell loss and microglial activation in the cerebellum after cortical contusion injury. Exp Neurol 203 (1):258-268
98. Koibuchi N (2009) Animal models to study thyroid hormone action in cerebellum. Cerebellum 8(2):89-97

99. Lalonde R, Strazielle C (2007) Spontaneous and induced mouse mutations with cerebellar dysfunctions: behavior and neurochemistry. Brain Res 1140:51-74

100. Zuo J, De Jager PI, Takahashi KA, Jiang W, Linden DJ, Heintz N (1997) Neurodegeneration in Lurcher mutant mice caused by mutation in the delta 2 glutamate receptor gene. Nature 388:769773

101. Lalouette A, Lohof A, Sotelo C, Guénet J, Mariani J (2001) Neurobiological effects of a null mutation depend on genetic context: comparison between two hotfoot alleles of the delta-2 ionotropic glutamate receptor. Neuroscience 105:443-455

102. Brown A, Bernier G, Mathieu M, Rossant J, Kothary R (1995) The mouse dystonia musculorum gene is a neural isoform of bullous pemphigoid antigen 1. Nat Genet 10:301-306

103. Lee NS, Jeong YG (2009) Pogo: a novel spontaneous ataxic mutant mouse. Cerebellum. doi:10.1007/s12311-009-0096-6

104. Hyun BH, Kim MS, Choi YK, Yoon WK, Suh JG, Jeong YG, Park SK, Lee CH (2001) Mapping of the pogo gene, a new ataxic mutant from Korean wild mice, on central mouse chromosome 8. Mamm Genome 12:250-252

105. Doyle J, Ren X, Lennon G, Stubbs L (1997) Mutations in the Cacnlla4 calcium channel gene are associated with seizures, cerebellar degeneration, and ataxia in tottering and leaner mutant mice. Mamm Genome 8:113-120

106. Pietrobon D (2005) Function and dysfunction of synaptic calcium channels: insights from mouse models. Curr Opin Neurobiol 15:257-265

107. Jeong YG, Kim MK, Hawkes R (2001) Ectopic expression of tyrosine hydroxylase in Zebrin II immunoreactive Purkinje cells in the cerebellum of the ataxic mutant mouse, pogo. Brain Res Dev Brain Res 129:201-209

108. Hess EJ, Wilson MC (1991) Tottering and leaner mutations perturb transient developmental expression of tyrosine hydroxylase in embryologically distinct Purkinje cells. Neuron 6:123132

109. Rhyu IJ, Oda S, Uhm CS, Kim H, Suh YS, Abbott LC (1999) Morphologic investigation of rolling mouse Nagoya ( $\operatorname{tg}(\mathrm{rol}) / \mathrm{tg}$ (rol)) cerebellar Purkinje cells: an ataxic mutant, revisited. Neurosci Lett 266:49-52

110. Sawada K, Komatsu S, Haga H, Oda S, Fukui Y (1999) Abnormal expression of tyrosine hydroxylase immunoreactivity in Purkinje cells precedes the onset of ataxia in dilute-lethal mice. Brain Res 844:188-191

111. Hawkes R, Herrup KJ (1995) Aldolase C/zebrin II and the regionalization of the cerebellum. Mol Neurosci 6:147-158

112. Plomp JJ, van den Maagdenberg AMJ, Kaja S (2009) The ataxic Cacnala-mutant mouse rolling Nagoya: an overview of neuromorphological and electrophysiological findings. Cerebellum. doi:10.1007/s12311-009-0117-5

113. Oda S (1973) The observation of rolling mouse Nagoya (rol), a new neurological mutant, and its maintenance. Jikken Dobutsu 22:281-288

114. Mori Y, Wakamori M, Oda S, Fletcher CF, Sekiguchi N, Mori E, Copeland NG, Jenkins NA, Matsushita K, Matsuyama Z, Imoto K (2000) Reduced voltage sensitivity of activation of P/Q-type $\mathrm{Ca} 2+$ channels is associated with the ataxic mouse mutation rolling Nagoya ( $\operatorname{tg}(\mathrm{rol}))$. J Neurosci 20:5654-5662

115. Felix R (2002) Insights from mouse models of absence epilepsy into $\mathrm{Ca} 2+$ channel physiology and disease etiology. Cell Mol Neurobiol 22:103-120

116. Soong BW, Paulson HL (2007) Spinocerebellar ataxias: an update. Curr Opin Neurol 20:438-446

117. Bitoun E, Davies KE. The robotic mouse: understanding the role of AF4, a cofactor of transcriptional elongation and chromatin 
remodelling, in Purkinje cell function. Cerebellum. doi:10.1007/ s12311-009-0101-0

118. Oliver PL, Keays DA, Davies KE (2007) Behavioural characterisation of the robotic mouse mutant. Behav Brain Res 181:239-247

119. Isaacs AM, Oliver PL, Jones EL, Jeans A, Potter A, Hovik BH et al (2003) A mutation in Af4 is predicted to cause cerebellar ataxia and cataracts in the robotic mouse. J Neurosci 23:16311637

120. Kapfhammer JP (2004) Cellular and molecular control of dendritic growth and development of cerebellar Purkinje cells. Prog Histochem Cytochem 39:131-182

121. Isnard P, Core N, Naquet P, Djabali M (2000) Altered lymphoid development in mice deficient for the mAF4 proto-oncogene. Blood 96:705-710

122. Oliver PL, Bitoun E, Clark J, Jones EL, Davies KE (2004) Mediation of Af4 protein function in the cerebellum by Siah proteins. Proc Natl Acad Sci U S A 101:14901-14906

123. Prasad R, Yano T, Sorio C, Nakamura T, Rallapalli R, Gu Y et al (1995) Domains with transcriptional regulatory activity within the ALL1 and AF4 proteins involved in acute leukemia. Proc Natl Acad Sci U S A 92:12160-12164

124. Gecz J, Gedeon AK, Sutherland GR, Mulley JC (1996) Identification of the gene FMR2, associated with FRAXE mental retardation. Nat Genet 13:105-108

125. Gu Y, McIlwain KL, Weeber EJ, Yamagata T, Xu B, Antalffy $\mathrm{BA}$ et al (2002) Impaired conditioned fear and enhanced longterm potentiation in Fmr2 knock-out mice. J Neurosci 22:27532763

126. Chen K, Godfrey DA, Ilyas O, Xu J, Preston TW. Cerebellumrelated characteristics of Scn8a-mutant mice. Cerebellum. doi:10.1007/s12311-009-0110-Z

127. Schaller KL, Krzemien DM, Yarowsky PL, Krueger BK, Caldwell JH (1995) A novel, abundant sodium channel expressed in neurons and glia. J Neurosci 15:3231-3242

128. Trudeau MM, Dalton JC, Day JW, Ranum LPW, Meisler MH (2006) Heterozygosity for a protein truncation mutation of sodium channel Scn8a in a patient with cerebellar atrophy, ataxia and mental retardation. J Med Genet 43:527-530

129. Burgess DL, Kohrman DC, Galt J, Plummer NW, Jones JM, Spear B, Meisler MH (1995) Mutation of a new sodium channel gene, Scn $8 \mathrm{a}$, in the mouse mutant 'motor endplate disease'. Nat Genet 10:461-465

130. Kohrman DC, Harris JB, Meisler MH (1996) Mutation detection in the med and medJ alleles of the sodium channel Scn8a. J Biol Chem 271:17576-17581

131. Howell VM, Jones JM, Bergren SK, Li L, Billi AC, Avenarius MR, Meisler MH (2007) Evidence for a direct role of the disease modifier SCNM1 in splicing. Hum Mol Genet 16:2506-2516

132. Preston TW, Chen K, Sprunger LK, Meisler MH, Godfrey DA (2001) GABA immunoreactivity in cochlear nucleus, inferior colliculus, and cerebellum of Scn8a mutant mice (medJ). Assoc Res Otolaryngol Abstr 24:197

133. Banerjee R, Vitvitsky V, Garg SK (2008) The undertow of sulfur metabolism on glutamatergic neurotransmission. Trends Biochem Sci 33:413-419

134. Vig PJS, Shao Q, Subramony SH, Lopez ME, Safaya E. Bergmann glial S100B activates myo-inositol monophosphatase 1 and co-localizes to Purkinje cell vacuoles in SCA1 transgenic mice. Cerebellum. doi:10.1007/s12311-009-0125-5

135. Skinner PJ, Vierra-Green CA, Clark HB, Zoghbi HY, Orr HT (2001) Altered trafficking of membrane proteins in Purkinje cells of SCA1 transgenic mice. Am J Pathol 159:905-913

136. Warrick JM, Paulson HL, Gray-Board GL, Bui QT, Fischbeck KH, Pittman RN, Bonini NM (1998) Expanded polyglutamine protein forms nuclear inclusions and causes neural degeneration in Drosophila. Cell 93(6):939-949
137. Riess O, Rüb U, Pastore A, Bauer P, Schöls L (2008) SCA3: neurological features, pathogenesis and animal models. Cerebellum 7(2):125-137

138. Wang HL, Yeh TH, Chou AH, Kuo YL, Luo LJ, He CY, Huang PC, Li AH (2006) Polyglutamine-expanded ataxin-7 activates mitochondrial apoptotic pathway of cerebellar neurons by upregulating Bax and downregulating $\mathrm{Bcl}-\mathrm{x}(\mathrm{L})$. Cell Signal 18 (4):541-552

139. Garden GA, La Spada AR (2008) Molecular pathogenesis and cellular pathology of spinocerebellar ataxia type 7 neurodegeneration. Cerebellum 7(2):138-149

140. Stevanin G, Brice A (2008) Spinocerebellar ataxia 17 (SCA17) and Huntington's disease-like 4 (HDL4). Cerebellum 7(2):170-178

141. Yamada M, Sato T, Tsuji S, Takahashi H (2008) CAG repeat disorder models and human neuropathology: similarities and differences. Acta Neuropathol 115(1):71-86

142. Berman RF, Willemsen R (2009) Mouse models of fragile Xassociated tremor ataxia. J Investig Med (in press)

143. Döhlinger S, Hauser TK, Borkert J, Luft AR, Schulz JB (2008) Magnetic resonance imaging in spinocerebellar ataxias. Cerebellum 7(2):204-214

144. Saksena S, Husain N, Malik GK, Trivedi R, Sarma M, Rathore RS, Pandey CM, Gupta RK (2008) Comparative evaluation of the cerebral and cerebellar white matter development in pediatric age group using quantitative diffusion tensor imaging. Cerebellum 7(3):392-400

145. Homburger F, Peterson J (1987) Experimental biology: genetic models in biomedical research. In: van Hoosier GL, McPherson CW (eds) Laboratory hamsters. Academic, Orlando, pp 251-262

146. Loscher W, Fisher JE Jr, Schmidt D, Fredow G, Honack D, Iturrian WB (1989) The sz mutant hamster: a genetic model of epilepsy or paroxysmal dystonia? Mov Disord 4:219-232

147. Peterson JS, de Groot CT, Yoon CH (1981) Five new mutations in the Syrian hamsters: fur loss, fur deficiency, juvenile gray, ashen, and quaking. J Hered 72:445-446

148. Akita K, Arai S (2009) The ataxic Syrian Hamster: an animal model homologous to the ped mutant mouse? Cerebellum. doi:10.1007/s12311-009-0113-9

149. Mullen RJ, Eicher EM, Sidman RL (1976) Purkinje cell degeneration, a new neurological mutation in the mouse. Proc Nat Acad Sci U S A 73:208-212

150. Fernandez-Gonzalez A, La Spada AR, Treadaway J, Higdon JC, Harris BS, Sidman RL, Morgan JI, Zuo J (2002) Purkinje cell degeneration (pcd) phenotypes caused by mutations in the axotomy-induced gene, Nna1. Science 295:1904-1906

151. Triarhou LC, Zhang W, Lee WH (1995) Graft-induced restoration of function in hereditary cerebellar ataxia. NeuroReport 6:1827-1832

152. Carrascosa C, Torres-Aleman I, Lopez-Lopez C, Carro E, Espejo L, Torrado S, Torrado JJ (2004) Microspheres containing insulinlike growth factor I for treatment of chronic neurodegeneration. Biomaterials 25:707-714

153. Wang T, Morgan JI (2007) The Purkinje cell degeneration (pcd) mouse: an unexpected molecular link between neuronal degeneration and regeneration. Brain Res 1140:26-40

154. Zang W, Ghetti B, Yang XL, Lee WH (1999) Alteration of IGF system gene expression during the postnatal development of pcd mice. J Endocrinol 163:191-198

155. Triarhou LC, Norton J, Alyea CJ, Ghetti B (1985) A quantitative study of the granule cells in Purkinje cell degeneration (pcd) mutant. Ann Neurol 18:146

156. O'Gorman S, Sidman RL (1985) Degeneration of thalamic neurons in "Purkinje cell degeneration" mutant mice. I. Distribution of neuron loss. J Comp Neurol 234:277-297

157. Ghetti B, Triarhou LC (1992) The Purkinje cell degeneration mutant: a model to study the consequences of neuronal 
degeneration. In: Plaitakis A (ed) Cerebellar degenerations: clinical neurobiology. Kluwer Academic, Boston, pp 159-181

158. Harris A, Morgan JI, Pecot M, Soumare A, Osborne A, Soares HD (2000) Regenerating motor neurons express Nna1, a novel ATP/GTP-binding protein related to zinc carboxypeptidase. Mol Cell Neurosci 16:578-596

159. Llorens JV, Navarro JA, Martínez-Sebastián MJ, Baylies MK, Schneuwly S, Botella JA, Moltó MD (2007) Causative role of oxidative stress in a Drosophila model of Friedreich ataxia. FASEB J 21:333-344

160. Sawamura N, Gong JS, Garver WS, Heidenreich RA, Ninomiya H, Ohno K, Yanagisawa K, Michikawa M (2001) Site-specific phosphorylation of tau accompanied by activation of mitogenactivated protein kinase (MAPK) in brains of Niemann-Pick type C mice. J Biol Chem 276:10314-10319

161. Sawamura N, Gong JS, Chang TY, Yanagisawa K, Michikawa M (2003) Promotion of tau phosphorylation by MAP kinase Erk1/2 is accompanied by reduced cholesterol level in detergentinsoluble membrane fraction in Niemann-Pick C1-deficient cells. J Neurochem 84(5):1086-1096

162. Bu B, Li J, Davies P, Vincent I (2002) Deregulation of cdk5, hyperphosphorylation, and cytoskeletal pathology in the Niemann-Pick type C murine model. J Neurosci 22:6515-6525

163. DeOme KB (1945) A new recessive lethal mutation in mice. Univ Calif Publ Zool 53:41-55

164. Kaye EM, Alroy J, Raghavan SS, Schwarting GA, Adelman LS, Runge V, Gelblum D, Thalhammer JG, Zuniga G (1992) Dysmyelinogenesis in animal model of GM1 gangliosidosis. Pediatr Neurol 8(4):255-261

165. Shell LG, Potthoff A, Carithers R, Katherman A, Saunders GK, Wood PA, Giger UL (1989) Neuronal-visceral GM, gangliosidosis in Portuguese water dogs. J Vet Intern Med 3:1-7

166. Ahern-Rindell AJ, Murnane RD, Prieur DJ (1989) Interspecies genetic complementation analysis of human and sheep fibroblasts with,-galactosidase deficiency. Somat Cell Genet 15:525533

167. Rodriguez M, O'Brien JS, Garrett RS, Powell HC (1982) Canine GM1-gangliosidosis. An ultrastructural and biochemical study. J Neuropathol Exp Neurol 41:618-629

168. Orgad U, Schelling S, Alroy J, Rosenberg A, Schiller A (1989) Skeletal lesions in lysosomal storage diseases. Lab Invest 60:68A

169. Alroy J, DeGasperi R, Warren CD (1991) Application of lectin histochemistry and carbohydrate analysis to the characterization of lysosomal storage diseases. Carbohydr Res 213:229-250

170. Alroy J, Orgad U, Ucci AA, Schelling SH, Schunk KL, Warren CD, Raghavan S, Kolodny EH (1985) Neurovisceral and skeletal GM1-gangliosidosis in dogs with P-galactosidase deficiency. Science 229:470-472

171. Li YT, Muhiudeen IA, DeGasperi R, Hirabayashi Y, Li SC (1983) Presence of activator proteins for the enzymic hydrolysis of GM, and GM2 gangliosides in normal human urine. Am J Hum Genet 35:629-634

172. Bingham MJ, Ong TJ, Summer KH, Middleton RB, McArdle HJ (1998) Physiologic function of the Wilson disease gene product, ATP7B. Am J Clin Nutr 67:982S-987S

173. Cuthbert JA (1995) Wilson's disease: a new gene and an animal model for an old disease. J Investig Med 43:323-336

174. Wu J, Forbes JR, Chen HS, Cox DW (1994) The LEC rat has a deletion in the copper transporting ATPase gene homologous to the Wilson disease gene. Nat Genet 7:541-545

175. Kato J, Kobune M, Kohgo Y, Sugawara N, Hisai H, Nakamura T, Sakamaki S, Sawada N, Niitsu Y (1996) Hepatic iron deprivation prevents spontaneous development of fulminant hepatitis and liver cancer in Long-Evans Cinnamon rats. J Clin Invest 98:923-929
176. Mori M, Hattori A, Sawaki M, Tsuzuki N, Sawada N, Oyamada M, Sugawara N, Enomoto K (1994) The LEC rat: a model for human hepatitis, liver cancer, and much more. Am J Pathol 144:200-204

177. Rauch H, Wells AJ (1995) The toxic milk mutation, tx, which results in a condition resembling Wilson disease in humans, is linked to mouse chromosome 8. Genomics 29:551-552

178. Hance N, Ekstrand MI, Trifunovic A (2005) Mitochondrial DNA polymerase gamma is essential for mammalian embryogenesis. Hum Mol Genet 14(13):1775-1783

179. Lewis W, Day BJ, Kohler JJ, Hosseini SH, Chan SS, Green EC, Haase CP, Keebaugh ES, Long R, Ludaway T, Russ R, Steltzer J, Tioleco N, Santoianni R, Copeland WC (2007) Decreased mtDNA, oxidative stress, cardiomyopathy, and death from transgenic cardiac targeted human mutant polymerase gamma. Lab Invest 87(4):326-335

180. Kasahara T, Kubota M, Miyauchi T, Noda Y, Mouri A, Nabeshima T, Kato T (2006) Mice with neuron-specific accumulation of mitochondrial DNA mutations show mood disorder-like phenotypes. Mol Psychiatry 11(6):577-593 523

181. Schott I, Hartmann D, Gieselmann V, Lüllmann-Rauch R (2001) Sulfatide storage in visceral organs of arylsulfatase A-deficient mice. Virchows Arch 439:90-96

182. Wittke D, Hartmann D, Gieselmann V, Lüllmann-Rauch R (2004) Lysosomal sulfatide storage in the brain of arylsulfatase A-deficient mice: cellular alterations and topographic distribution. Acta Neuropathol (Berl) 108:261-271

183. Isaac G, Pernber Z, Gieselmann V, Hansson E, Bergquist J, Mansson JE (2006) Sulfatide with short fatty acid dominates in astrocytes and neurons. FEBS J 273:1782-1790

184. Hahn P, Qian Y, Dentchev T, Chen L, Beard J, Harris ZL, Dunaief JL (2004) Disruption of ceruloplasmin and hephaestin in mice causes retinal iron overload and retinal degeneration with features of age-related macular degeneration. Proc Natl Acad Sci U S A 101(38):13850-13855

185. Greenough WT, Klintsova AY, Irwin SA, Galvez R, Bates KE, Weiler IJ (2001) Synaptic regulation of protein synthesis and the fragile X protein. Proc Nat Acad Sci 98:7101-7106

186. Irwin SA, Idupulapati M, Gilbert ME, Harris JB, Chakravarti AB, Rogers EJ, Crisostomo RA, Larsen BP, Mehta A, Alcantara CJ, Patel B, Swain RA, Weiler IJ, Oostra BA, Greenough WT (2002) Dendritic spine and dendritic field characteristics of layer $\mathrm{V}$ pyramidal neurons in the visual cortex of fragile-X knockout mice. Am J Med Genet 111:140-146

187. Koekkoek SKE, Yamaguchi K, Milojkovic BA, Dortland BR, Ruigrok TJH, Maex R, De Graaf W, Smit AE, VanderWerf F, Bakker CE, Willemsen R et al (2005) Deletion of FMR1 in Purkinje cells enhances parallel fiber LTD, enlarges spines, and attenuates cerebellar eyelid conditioning in fragile $\mathrm{X}$ syndrome. Neuron 47:339-352

188. Peier AM, McIlwain KL, Kenneson A, Warren ST, Paylor R, Nelson DL (2000) (Over)correction of FMR1 deficiency with YAC transgenics: behavioral and physical features. Hum Mol Genet 9:1145-1159

189. Zhang YQ, Bailey AM, Matthies HJG, Renden RB, Smith MA, Speese SD, Rubin GM, Broadie K (2001) Drosophila fragile Xrelated gene regulates the MAP1B homolog Futsch to control synaptic structure and function. Cell 107:591-603

190. Pujol A, Hindelang C, Callizot N, Bartsch U, Schachner M, Mandel JL (2002) Late onset neurological phenotype of the XALD gene inactivation in mice: a mouse model for adrenomyeloneuropathy. Hum Mol Genet 11:499-505

191. Lu JF, Lawler AM, Watkins PA, Powers JM, Moser AB, Moser HW, Smith KD (1997) A mouse model for X-linked adrenoleukodystrophy. Proc Nat Acad Sci USA 94:9366-9371

192. Pujol A, Ferrer I, Camps C, Metzger E, Hindelang C, Callizot N, Ruiz M, Pàmpols T, Giròs M, Mandel JL (2004) Functional 
overlap between $\mathrm{ABCD} 1$ (ALD) and $\mathrm{ABCD} 2$ (ALDR) transporters: a therapeutic target for X-adrenoleukodystrophy. Hum Mol Genet 13:2997-3006

193. Collins AL, Levenson JM, Vilaythong AP, Richman R, Armstrong DL, Noebels JL, David Sweatt J, Zoghbi HY (2004) Mild overexpression of $\mathrm{MeCP} 2$ causes a progressive neurological disorder in mice. Hum Mol Genet 13:2679-2689

194. Potts MB, Adwanikar H, Noble-Haeusslein LJ (2009) Models of traumatic cerebellar injury. Cerebellum. doi:10.1007/s12311009-0114-8

195. Braga LW, Souza LN, Najjar YJ, Dellatolas G (2007) Magnetic resonance imaging (MRI) findings and neuropsychological sequelae in children after severe traumatic brain injury: the role of cerebellar lesion. J Child Neurol 22(9):1084-1089

196. Basford JR, Chou LS, Kaufman KR, Brey RH, Walker A, Malec JF et al (2003) An assessment of gait and balance deficits after traumatic brain injury. Arch Phys Med Rehabil 84(3):343-349

197. Louis ED, Lynch T, Ford B, Greene P, Bressman SB, Fahn S (1996) Delayed-onset cerebellar syndrome. Arch Neurol 53 (5):450-454

198. Soto-Ares G, Vinchon M, Delmaire C, Abecidan E, Dhellemes P, Pruvo JP (2001) Cerebellar atrophy after severe traumatic head injury in children. Childs Nerv Syst 17(4-5):263-269

199. Thompson HJ, Lifshitz J, Marklund N, Grady MS, Graham DI, Hovda DA et al (2005) Lateral fluid percussion brain injury: a 15-year review and evaluation. J Neurotrauma 22(1):42-75

200. Marmarou A, Foda MA, van den Brink W, Campbell J, Kita H, Demetriadou K (1994) A new model of diffuse brain injury in rats. Part I: pathophysiology and biomechanics. J Neurosurg 80 (2):291-300

201. Tuzgen S, Tanriover N, Uzan M, Tureci E, Tanriverdi T, Gumustas K et al (2003) Nitric oxide levels in rat cortex, hippocampus, cerebellum, and brainstem after impact acceleration head injury. Neurol Res 25(1):31-34

202. Gutierrez E, Huang Y, Haglid K, Bao F, Hansson HA, Hamberger A et al (2001) A new model for diffuse brain injury by rotational acceleration: I model, gross appearance, and astrocytosis. J Neurotrauma 18(3):247-257

203. Runnerstam M, Bao F, Huang Y, Shi J, Gutierrez E, Hamberger A et al (2001) A new model for diffuse brain injury by rotational acceleration: II. Effects on extracellular glutamate, intracranial pressure, and neuronal apoptosis. J Neurotrauma 18(3):259-273

204. Ai J, Baker A (2004) Presynaptic excitability as a potential target for the treatment of the traumatic cerebellum. Pharmacology 71 (4):192-198

205. Dusart I, Sotelo C (1994) Lack of Purkinje cell loss in adult rat cerebellum following protracted axotomy: degenerative changes and regenerative attempts of the severed axons. J Comp Neurol 347(2):211-232

206. Culic M, Blanusa LM, Grbic G, Spasic S, Jankovic B, Kalauzi A (2005) Spectral analysis of cerebellar activity after acute brain injury in anesthetized rats. Acta Neurobiol Exp (Wars) 65(1):1117

207. Carulli D, Buffo A, Strata P (2004) Reparative mechanisms in the cerebellar cortex. Prog Neurobiol 72(6):373-398

208. Rossi F, Gianola S, Corvetti L (2006) The strange case of Purkinje axon regeneration and plasticity. Cerebellum 5(2):174182

209. Faden AI (2002) Neuroprotection and traumatic brain injury: theoretical option or realistic proposition. Curr Opin Neurol 15:707-712

210. Viscomi MT, Florenzano F, Conversi D, Bernardi G, Molinari M (2004) Axotomy dependent purinergic and nitrergic coexpression. Neuroscience 123:393-404

211. Viscomi MT, Latini L, Florenzano F, Bernardi G, Molinari M (2008) Minocycline attenuates microglial activation but fails to mitigate degeneration in inferior olive and pontine nuclei after focal cerebellar lesion. Cerebellum 7:401-405

212. Loddick SA, Rothwell NJ (1996) Neuroprotective effects of human recombinant interleukin-1 receptor antagonist in focal cerebral ischaemia in the rat. J Cereb Blood Flow Metab 16:932940

213. Sriram K, Miller DB, O'Callaghan JP (2006) Minocycline attenuates microglial activation but fails to mitigate striatal dopaminergic neurotoxicity: role of tumor necrosis factor-alpha. J Neurochem 96:706-718

214. Bist R, Bhatt DK (2009) The evaluation of effect of alpha-lipoic acid and vitamin $\mathrm{E}$ on the lipid peroxidation, gamma-amino butyric acid and serotonin level in the brain of mice (Mus musculus) acutely intoxicated with lindane. J Neurol Sci 276(12):99-102

215. Sanders T, Liu Y, Buchner V, Tchounwou PB (2009) Neurotoxic effects and biomarkers of lead exposure: a review. Rev Environ Health 24(1):15-45

216. Dlugos CA (2008) Ethanol-related increases in degenerating bodies in the Purkinje neuron dendrites of aging rats. Brain Res 1221:98-107

217. Bonthius DJ, Bonthius NE, Li S, Karacay B (2008) The protective effect of neuronal nitric oxide synthase (nNOS) against alcohol toxicity depends upon the NO-cGMP-PKG pathway and NF-kappaB. Neurotoxicology 29(6):1080-1091

218. Groebe A, Clarner T, Baumgartner W, Dang J, Beyer C, Kipp M. Cuprizone treatment induces distinct demyelination, astrocytosis, and microglia cell invasion or proliferation in the mouse cerebellum. Cerebellum. doi:10.1007/s12311-009-0099-3

219. Craner MJ, Lo AC, Black JA, Baker D, Newcombe J, Cuzner ML et al (2003) Annexin II/p11 is up-regulated in Purkinje cells in EAE and MS. Neuroreport 14(4):555-558

220. Franklin RJ, French-Constant C (2008) Remyelination in the CNS: from biology to therapy. Nat Rev Neurosci 9(11):839-855

221. Lassmann H, Bruck W, Lucchinetti C (2001) Heterogeneity of multiple sclerosis pathogenesis: implications for diagnosis and therapy. Trends Mol Med 7(3):115-121

222. Matsushima GK, Morell P (2001) The neurotoxicant, cuprizone, as a model to study demyelination and remyelination in the central nervous system. Brain Pathol 11(1):107-116

223. Kipp M, Norkute A, Johann S, Lorenz L, Braun A, Hieble A et al (2008) Brain-region-specific astroglial responses in vitro after LPS exposure. J Mol Neurosci 35(2):235-243

224. Johann S, Kampmann E, Denecke B, Arnold S, Kipp M, Mey J et al (2008) Expression of enzymes involved in the prostanoid metabolism by cortical astrocytes after LPS-induced inflammation. J Mol Neurosci 34(2):177-185

225. Louis ED, Faust PL, Vonsattel JP, Honig LS, Henchcliffe C, Pahwa R, Lyons KE, Rios E, Erickson-Davis C, Moskowitz CB, Lawton A (2009) Older onset essential tremor: more rapid progression and more degenerative pathology. Mov Disord (in press)

226. Martin FC, Handforth A (2006) Carbenoxolone and mefloquine suppress tremor in the harmaline mouse model of essential tremor. Mov Disord 21(10):1641-1649

227. Kumar A, Ali M, Mishra P, Pandey BN, Sharma P, Mishra KP (2009) Thorium-induced neurobehavioural and neurochemical alterations in Swiss mice. Int J Radiat Biol 85(4):338-347

228. Sakamoto M, Kakita A, de Oliveira RB, Sheng Pan H, Takahashi H (2004) Dose-dependent effects of methylmercury administered during neonatal brain spurt in rats. Brain Res Dev Brain Res 152 (2): $171-176$

229. Denver RJ, Williamson KE (2009) Identification of a thyroid hormone response element in the mouse Kruppel-like factor 9 gene to explain its postnatal expression in the brain. Endocrinology 150(8):3935-3943 
230. Kimura-Kuroda J, Nagata I, Kuroda Y (2008) Hormonal disruption in cerebellar development by hydroxylated polychlorinated biphenyls. Cerebellum 7(3):500-501

231. Jetten AM (2009) Retinoid-related orphan receptors (RORs): critical roles in development, immunity, circadian rhythm, and cellular metabolism. Nucl Recept Signal 7:e003

232. Koibuchi N, Kimura-Kuroda J, Ikeda Y, Tsutsui K (2008) Cerebellum, a target for hormonal signaling. Cerebellum 7 (3):499

233. Dong H, Yauk CL, Rowan-Carroll A, You SH, Zoeller RT, Lambert I, Wade MG (2009) Identification of thyroid hormone receptor binding sites and target genes using ChIP-on-chip in developing mouse cerebellum. PLoS ONE 4(2):e4610

234. Koibuchi N, Qiu CH, Miyazaki W, Iwasaki T, Shimokawa N (2008) The role of thyroid hormone in developing cerebellum. Cerebellum 7(3):499-500

235. Tsutsui K, Haraguchi S, Inoue K, Miyabara H, Suzuki S, Ogura Y, Koyama T, Matsunaga M, Vaudry H (2009) Identification, biosynthesis, and function of 7alpha-hydroxypregnenolone, a new key neurosteroid controlling locomotor activity, in nonmammalian vertebrates. Ann N Y Acad Sci 1163:308-315

236. Sakamoto H, Ukena K, Kawata M, Tsutsui K (2008) Expression, localization and possible actions of $25-\mathrm{Dx}$, a membrane associated putative progesterone-binding protein, in the developing Purkinje cell of the cerebellum: a new insight into the biosynthesis, metabolism and multiple actions of progesterone as a neurosteroid. Cerebellum 7(1):18-25

237. Tsutsui K (2008) Neurosteroid synthesis and action in the cerebellum during development. Cerebellum 7(3):502-504

238. Robin G, Jonard S, Vuillaume I, Devos D, Dewailly D (2005) Hypogonadotropic hypogonadism discovered in a patient with cerebellar ataxia. Ann Endocrinol (Paris) 66 (6):545-551
239. Albertson AJ, Talbott H, Wang Q, Jensen D, Skinner DC (2008) The gonadotropin-releasing hormone type I receptor is expressed in the mouse cerebellum. Cerebellum 7(3):379-384

240. Sajdel-Sulkowska EM (2008) Brain development, environment and sex: what can we learn from studying graviperception, gravitransduction and the gravireaction of the developing CNS to altered gravity? Cerebellum 7(3):223-239

241. Sebastian CE, Pfau K, Horn ER (1998) An age-dependent sensitivity of the roll-induced vestibuloocular reflex to hypergravity exposure of several days in an amphibian (Xenopus laevis). Acta Astronaut 42(1-8):419-430

242. Horn E, Sebastian C (2002) Adaptation of the macular vestibuloocular reflex to altered gravitational conditions in a fish (Oreochromis mossambicus). Adv Space Res 30(4):711-720

243. Marshall SP, Van Der Giessen RS, De Zeeuw CI, Lang EJ (2007) Altered olivocerebellar activity patterns in the connexin36 knockout mouse. Cerebellum 6:287-299

244. Alvarez MI, Lacruz C, Toledano-Díaz A, Monleón E, Monzón M, Badiola JJ, Toledano A (2008) Calretinin-immunopositive cells and fibers in the cerebellar cortex of normal sheep. Cerebellum 7(3):417-429

245. Sultan F, Glickstein M (2007) The cerebellum: comparative and animal studies. Cerebellum 6(3):168-176

246. Hirai H (2008) Progress in transduction of cerebellar Purkinje cells in vivo using viral vectors. Cerebellum 7(3):273-278

247. Jin D, Liu HX, Hirai H, Torashima T, Nagai T, Lopatina O, Shnayder NA, Yamada K, Noda M, Seike T, Fujita K, Takasawa S, Yokoyama S, Koizumi K, Shiraishi Y, Tanaka S, Hashii M, Yoshihara T, Higashida K, Islam MS, Yamada N, Hayashi K, Noguchi N, Kato I, Okamoto H, Matsushima A, Salmina A, Munesue T, Shimizu N, Mochida S, Asano M, Higashida H (2007) CD38 is critical for social behaviour by regulating oxytocin secretion. Nature 446(7131):41-45 